\title{
"Increasing contingent guarantees: The asymmetrical effect on sovereign risk of different government interventions"
}

Manish K. Singh, Marta Gómez-Puig, Simón Sosvilla-Rivero 


\section{UBREA \\ Institut de Recerca en Economia \\ Aplicada Regional i Pública \\ UNIVERSITAT DE BARCELONA}

WEBSITE: www.ub.edu/irea/•CONTACT: irea@ub.edu

The Research Institute of Applied Economics (IREA) in Barcelona was founded in 2005, as a research institute in applied economics. Three consolidated research groups make up the institute: AQR, RISK and GiM, and a large number of members are involved in the Institute. IREA focuses on four priority lines of investigation: (i) the quantitative study of regional and urban economic activity and analysis of regional and local economic policies, (ii) study of public economic activity in markets, particularly in the fields of empirical evaluation of privatization, the regulation and competition in the markets of public services using state of industrial economy, (iii) risk analysis in finance and insurance, and (iv) the development of micro and macro econometrics applied for the analysis of economic activity, particularly for quantitative evaluation of public policies.

IREA Working Papers often represent preliminary work and are circulated to encourage discussion. Citation of such a paper should account for its provisional character. For that reason, IREA Working Papers may not be reproduced or distributed without the written consent of the author. A revised version may be available directly from the author.

Any opinions expressed here are those of the author(s) and not those of IREA. Research published in this series may include views on policy, but the institute itself takes no institutional policy positions. 
Government interventions to support the financial institutions fall into two broad categories: direct interventions (which immediately increase the government's financing need) and offbalance sheet contingent guarantees (which have no immediate impact on debt but will add to government debt as and when a loss materializes). If financial sector losses are independent of sovereign's own risk, all else being equal, they must have the same effect on the sovereign's risk profile, even though they impact the government balance sheet differently. In this paper, we study the nature and effectiveness of a government's interventions on its own risk profile. Our findings suggest that direct assistance has a significantly large effect on sovereign risk, while the effect of contingent guarantees is statistically not significant, being significant only for the euro area founders. Controlling for government interventions, we also find that GDP, perceived government effectiveness, economic sentiment, size of the financial sector, and membership of the euro area reduce the sovereign risk, while asset concentration within financial sector, unemployment and inflation have an adverse effect. Our findings support Bresciani and Cossaro (2016)'s claim that during the sovereign debt crisis, governments undertook complex financial operations to change the composition of their interventions towards contingent guarantees.

JEL classification: $\mathrm{G} 01, \mathrm{H} 63$

Keywords: sovereign risk, financial assistance, fiscal capacity, bailout, contingent guarantee

Manish K. Singh: Department of Management Studies, Indian Institute of Technology Delhi, India.E-mail: mks@iitd.ac.in

Marta Gómez-Puig: Department of Economics \& Riskcenter, Universitat de Barcelona, Spain E-mail: marta.gomezpuig@ub.edu

Simón Sosvilla-Rivero: Complutense Institute of Economic Analysis (ICAE), Universidad Complutense de Madrid, Spain. E-mail: sosvilla@ccee.ucm.es 


\title{
Increasing contingent guarantees: The asymmetrical effect on sovereign risk of different government interventions
}

\author{
Manish K. Singh ${ }^{\mathrm{a}}$, Marta Gómez-Puig ${ }^{\mathrm{b}, *}$, Simón Sosvilla-Rivero ${ }^{\mathrm{c}}$ \\ ${ }^{a}$ Department of Management Studies, Indian Institute of Technology Delhi, India \\ E-mail: mks@iitd.ac.in \\ ${ }^{b}$ Department of Economics $\& 3$ Riskcenter, Universitat de Barcelona, Spain \\ E-mail: marta.gomezpuig@ub.edu \\ ${ }^{c}$ Complutense Institute of Economic Analysis (ICAE), Universidad Complutense de Madrid, Spain \\ E-mail: sosvilla@ccee.ucm.es
}

\begin{abstract}
Government interventions to support the financial institutions fall into two broad categories: direct interventions (which immediately increase the government's financing need) and offbalance sheet contingent guarantees (which have no immediate impact on debt but will add to government debt as and when a loss materializes). If financial sector losses are independent of sovereign's own risk, all else being equal, they must have the same effect on the sovereign's risk profile, even though they impact the government balance sheet differently. In this paper, we study the nature and effectiveness of a government's interventions on its own risk profile. Our findings suggest that direct assistance has a significantly large effect on sovereign risk, while the effect of contingent guarantees is statistically not significant, being significant only for the euro area founders. Controlling for government interventions, we also find that GDP, perceived government effectiveness, economic sentiment, size of the financial sector, and membership of the euro area reduce the sovereign risk, while asset concentration within financial sector, unemployment and inflation have an adverse effect. Our findings support Bresciani and Cossaro (2016)'s claim that during the sovereign debt crisis, governments undertook complex financial operations to change the composition of their interventions towards contingent guarantees.
\end{abstract}

Keywords: sovereign risk, financial assistance, fiscal capacity, bailout, contingent guarantee

JEL: G01, H63

\section{Introduction}

In a severe financial crisis, countries need sufficient financial resources to support their financial system (see Tagkalakis (2012), Maurer and Grussenmeyer (2015), Millaruelo and

\footnotetext{
*Corresponding author. Tel: +34 934020113; Fax: +34 934039082

Departament d'Economia, Universitat de Barcelona, Diagonal 696, Barcelona 08034, Spain.
} 
del Río (2017)). The potential fiscal costs depend on the structure of the financial system ${ }^{1}$ and may be unevenly distributed. ${ }^{2}$ Hüttl and Schoenmaker (2016) estimated that for the euro area, the recapitalization of banks may cost anywhere between 4 and $12 \%$ of GDP for different countries. In a systemic crisis, the bail-in of private investors will not be fully possible and even the fiscal resources of some countries might be insufficient (see Sgherri and Zoli (2009), Correa et al. (2014)). The sovereign will then require outside support which will further add to the macroeconomic instability.

During the recent European sovereign debt crisis (2009-12), most countries realized that the bail-in of private investors was insufficient. The financial sector needed external assistance and most countries bore this cost at least partially. Since then, a sizable volume of public resources has been committed to stabilizing and restructuring the financial system (see Millaruelo and del Río (2017) for detailed description). According to information available at the European Commission's (EC) Directorate General for Competition website (Table 1), the total amount of state aid used by the EU-28 countries between 2008 and 2015 was estimated at a value of roughly 1.95 trillion euros (465.6 billion for recapitalizations, 188.6 billion for impaired assets, 105 billion for liquidity support and 1188.1 billion in the form of guarantees). ${ }^{3}$

Table 1: Total amount of state aid approved and used, EU-28 (2008-2015)

\begin{tabular}{lrrrr} 
& \multicolumn{2}{c}{ Amount Approved } & \multicolumn{2}{c}{ Amount Used } \\
Aid instruments & EUR billion & $\%$ 2015 EU GDP & EUR billion & $\% 2015$ EU GDP \\
\hline \multirow{2}{*}{ Recapitalization } & 820.9 & $5.6 \%$ & 465.6 & $3.2 \%$ \\
Impaired asset measures & 604.3 & $4.1 \%$ & 188.6 & $1.3 \%$ \\
Liquidity support & 229.7 & $1.6 \%$ & 105 & $0.7 \%$ \\
\hline \multirow{2}{*}{ Guarantees on liabilities } & 3311.2 & $22.6 \%$ & 1188.1 & $8.1 \%$ \\
\hline
\end{tabular}

Note: Amount of aid approved and used are the maximum outstanding amounts (annual) during the period 2008-2015. Source: European Commission.

However, not all state aid has an equal and immediate impact on the country's fiscal situation. A distinction must be drawn between direct loans to financial institutions, recapitalization and asset restructuring measures with respect to the contingent guarantees. The first three require an immediate disbursement of funds and therefore increase the sovereign's borrowing requirement immediately. ${ }^{4}$ On the other hand, the granting of public guarantees is considered as a contingent liability with no impact on the deficit or debt, unless the

\footnotetext{
${ }^{1}$ Langfield and Pagano (2016) documents the adverse effects of the bank-based financial structure developed in Europe and the resulting impact on systemic risk and economic growth.

${ }^{2}$ It depends on a multitude of factors like the size of the financial sector, the asset concentration within banks and the composition of public and private debt, among others.

${ }^{3}$ Source: http://ec.europa.eu/competition/state_aid/scoreboard/index_en.html

${ }^{4} \mathrm{An}$ increase in the borrowing requirement does not automatically translate into losses. Think of loans. These are financial transactions, which adds to both sides (assets and liabilities) of the general government balance sheet. Also, it will add to the government losses only when the reference entity defaults on its
} 
guarantee is realized and the government has to make a payment or assume a debt. In the meantime, they are a source of funds via the attendant commission fees. Experience also suggests that during a severe financial crisis, governments undertake complex financial operations to change the composition of their interventions towards contingent guarantees (see Bresciani and Cossaro (2016)). Assuming the difficulty in raising capital in a severe crisis, this helps cushion the impact of the financial crisis on the sovereign's own creditworthiness.

This paper studies the impact of government intervention on sovereign risk based on the type of instrument used to support the financial institutions during the ongoing financial and sovereign debt crisis. We classify the financial assistance measures into two broad categories: (1) Direct assistance (support measures that increased the government's financing requirement immediately) and (2) Contingent guarantee (support that will increase the financing requirement over time as and when the loss materializes). Given a choice between direct assistance or contingent guarantee, we aim to understand the financial benefit of using one against the other by quantifying their impact on sovereign risk. ${ }^{5}$ As pointed out by Hüttl and Schoenmaker (2016), if the divergence in financing conditions across the banking union is actually reflecting the strength of fiscal backstops in different countries and fiscal resources are limited, it might be a good idea to think of ways to employ the fiscal resources prudently (see Bova et al. (2016)).

Given that the public interventions in the banking sector proved to be an important channel feeding the negative spillovers between banks' and sovereign's stability, even when the banks did not hold sovereign bonds (see Leonello (2017)), we ask the following questions: (1) Is an increase in the level of financial assistance always associated with an increase in sovereign risk?; and (2) Does the design of public interventions have implications for the stabilization of sovereign risk?

The analysis in the paper provides a number of novel results about the effect of government support on the sovereign risk profile. First, even though both forms of financial assistance (direct assistance and contingent guarantee) are temporary in nature, direct assistance is significantly more expensive. This is so because the provision of direct assistance requires immediate disbursement of the resources available to the government, which in turn are determined by the sovereign's current risk profile. In times of crisis, if a large amount needs to be transferred to the banking sector while the government's fiscal space is limited, the direct intervention will have a direct detrimental effect on the sovereign's solvency.

repayment obligations. For recapitalization and impaired asset measures, depending on their characteristics and conditions, they may be considered either as a financial investment, as a capital transfer, or as a combination of both. If what is involved is a financial investment, they will give rise to an increase in financial assets on the general government balance sheet, whereas when they are a capital transfer covering cumulative losses (or above market value transaction), this will entail a direct loss for the government for the related period. The subsequent sale of the asset or of the capital holdings at a lower price than that at which they were acquired will generate losses, while if it is sold at a higher price, it may be profitable for the government.

${ }^{5}$ Honohan and Klingebiel (2003) provide empirical evidence whether the design of crisis containment and resolution policies can systematically influence the overall magnitude of fiscal costs. However, we differ and try to estimate the effect based on the type of financial assistance measure without taking view on the underlying policy objective. 
Second, the contingent guarantee does not significantly affect the sovereign risk. This result is counter-intuitive and against the findings of Arslanalp and Liao (2014). By improving banks' available resources, guarantees have a direct beneficial effect on financial stability. However, by increasing the sovereign's contingent liability, they must have a direct detrimental effect on sovereign solvency. One possible explanation is that guarantees indirectly affect each probability, because the likelihood of a banking crisis and that of a sovereign default affect one another. As pointed out by Leonello (2017), by reducing the probability of a banking crisis, guarantees reduce the instances in which the government transfers resources to the banking sector, thus improving sovereign stability. Overall, the analysis suggests that policies addressing the design of financial intervention schemes and their funding are important for limiting the sovereign's own fragility.

The novelty of the paper is the empirical analysis of the effects of different components of financial assistance measures in a context in which the government can choose between direct intervention and contingent guarantee. Since the government's budget is limited and both banks and the government are fragile, it is of utmost importance to address the financial assistance design and its funding while limiting the impact on the sovereign's own risk. To our knowledge, this is the first empirical paper to provides counter-evidence to the assumption in public interventions in banking that all sovereign interventions - direct or contingent - have a similar impact on the sovereign's risk profile. It also provides support to the argument that credibility and effectiveness of the guarantees are intertwined with the sovereign funding risk (see König et al. (2014), Leonello (2017)).

The rest of the paper proceeds as follows. Section 2 documents the various financial instruments that were used in the recent crisis. A comparison of the direct cost associated with these measures and their contribution to increasing government debt is also discussed. Section 3 presents the data. Section 4 analyzes the effect of the different measures on sovereign risk to determine which ones the government should use, given a choice between contingent guarantee and direct assistance. Section 5 examines a number of robustness exercises. Finally, Section 6 offers some concluding remarks.

\section{Government interventions}

During the recent financial crisis, governments across the globe undertook complicated and substantial financial operations to support distressed financial institutions. However, a closer look at the underlying economic dynamics of these interventions suggests that they can be classified into two broad categories. In the majority of these transactions, the troubled asset moved from the books of financial institutions to the balance sheet of the sovereign. In order to facilitate this transaction, the sovereign used cash, issued debt or liquidated some other asset holding. For the rest, the sovereign provided a fiscal backstop in the form of contingent guarantee in return for a fee, while the troubled asset still lay in the books of the financial institutions. Figure 1 summarizes these differences in chart form.

To highlight and contrast the differences between these assistance measures, let us look at the direct assistance mechanism. Imagine at time $t=0$, a government decision to interfere in the financial market to corner a particular asset class - what we could call a troubled 
Figure 1: Direct assistance vs Contingent guarantee

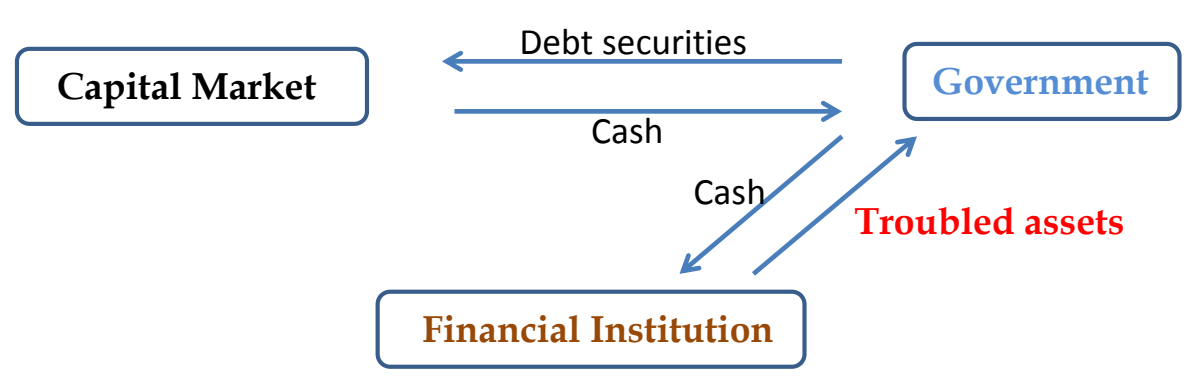

(a) Targeted interventions

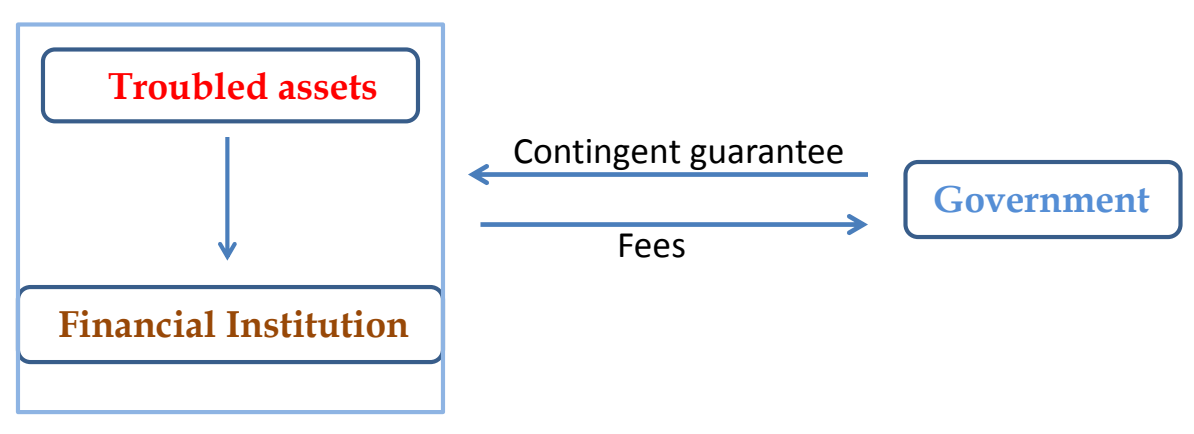

(b) Contingent guarantees

asset. Assume that the sovereign issued treasury securities to finance this transaction. The proceeds of the debt sold will be transferred to the financial institution in return for the troubled asset. Going forward, the sovereign will receive a stream of income from the troubled assets it acquired $\left(i_{a, t}\right)^{6}$ and will pay interest on the newly issued debt $\left(i_{s, t}\right)$. Figure 2 shows this graphically. The blue and red lines represent the cash flows from the sovereign debt and troubled assets respectively. The sovereign will have to finance the acquisition of asset at $t=0$ and the difference $\left(i_{s, t}-i_{a, t}\right)$ at all future times $(t \geq 1)$. The underlying assumption behind this bailout strategy is that the cost of sovereign debt $\left(i_{s, t}\right)$ will be lower than the cost of capital for the financial institutions and the sovereign has excess fiscal space; therefore the financial institution will be stabilized. On the other hand, if the sovereign decides not to buy the asset but instead provide the contingent guarantee, the payout for the sovereign will be the difference $E\left(i_{a, t}\right)-i_{a, t}$ for all $t \geq 1$, where $E\left(i_{a, t}\right)$ is the income expected from the troubled asset.

Note that when the sovereign decides to buy the assets, the acquisition will cost it an extra amount, which is the cost of borrowing for the sovereign $\left(i_{s, t}\right)$. This additional amount

\footnotetext{
${ }^{6}$ This will be a dividend if the troubled asset is equity, and interest plus principle receivable in the case of debt or loans.
} 


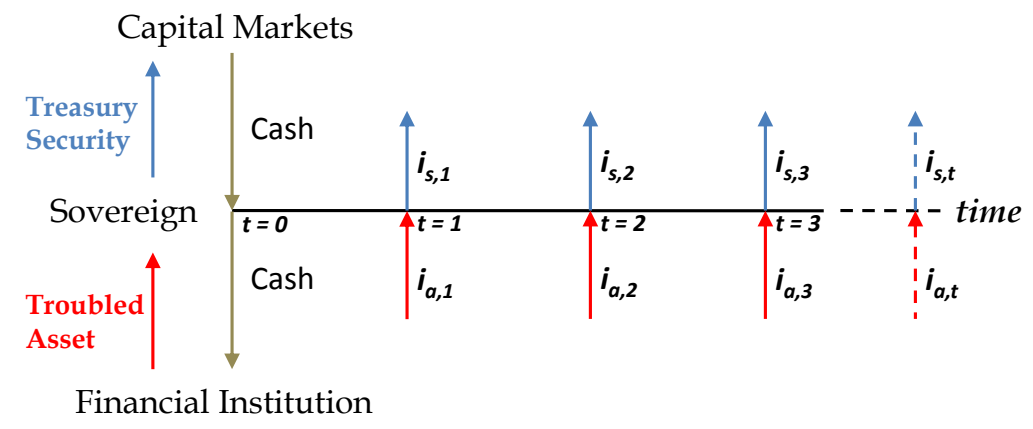

is over and above the direct losses that will materialize because of the non-performance of the asset acquired $\left(E\left(i_{a, t}\right)-i_{a, t}\right)$. This cost has to be paid regularly and will be borne by the sovereign till either debt is repaid or the acquired assets are sold. So the asset which is directly acquired has to outperform (i.e., offer a higher interest rate) the cost of sovereign debt as long as it is on the sovereign's balance sheet; otherwise, the sovereign is paying interest while not receiving anything from the acquired asset or might suffer multiple losses - paying interest on the borrowed fund and suffering losses on the acquired assets.

On the other hand, the contingent guarantee will earn a guarantee fee before the actual loss materializes. So the resultant loss will be lower than or equal to $\left(E\left(i_{a, t}\right)-i_{a, t}\right)$. This can help the sovereign buy some time before accepting the loss in times of crisis. Also, even if it materializes, the sovereign only has to bear the defaulted amount (a small fraction of the whole amount) and it will be distributed across time. This is especially relevant in the time of sovereign crisis, as the cost of raising debt is high and the sovereign can enter the vicious spiral in which increasing amount and cost of debt can translate into insolvency.

Table 2 provides a summary of the various interventions and their classification in direct versus contingent assistance. Appendix A explains each component in greater details. 
Table 2: Nature of governments' financial sector assistance measure

\section{Direct assistance}

1. Capital injections supporting financial institutions

$$
\begin{array}{r}
\mathrm{Up} \\
\mathrm{Up} \\
\text { Down } \\
\text { Down } \\
\mathrm{Up} \\
\text { Down } \\
\mathrm{Up} \\
\text { Down } \\
\mathrm{Up} \\
\mathrm{Up}
\end{array}
$$

2. Acquisition of equities (at or above market price)

- Dividends receivable: Indirect revenue

- Subsequent sales of shares: Capital recovery

- Interest receivable: Indirect revenue

4. Provision of loans

$\begin{array}{lr}\text { - Interest receivable: Indirect revenue } & \text { Down } \\ \text { Up }\end{array}$

5. Debt assumptions
- Interest payable: Capital transfer

6. Assets and liabilities of newly created government defeasance structures (bad banks)

7. Other assets and liabilities from entities reclassified from other sector

None to general government without transactions

\section{Contingent guarantees}

1. Guarantee on assets or liabilities outside general government

- Guarantee fees: Indirect revenue

- Called government guarantees: Capital transfer

2. Guarantee on securities issued under liquidity schemes

Note: Special purpose entities included here are those where the government has a significant role, including a guarantee, but which are classified outside the general government sector. Their liabilities are recorded outside the general government sector as contingent liabilities of the general government. Source: Eurostat - Supplementary tables for reporting government interventions to support financial institutions.

\section{Data}

The main sample includes 23 European countries over the period 2007 to 2016. It includes all countries for which consecutive data on government interventions to support financial institutions are available. Table 3 provides an overview of our sample. The rest of the section describes the data in more detail.

\subsection{Sovereign risk measure (SovYield)}

We use the benchmark ten-year long-term interest rates as our dependent variable to measure the sovereign risk. These are the rates used as a convergence criterion to adopt the euro, based on the Maastricht Treaty. The rates are based on the yield of ten-year government bonds traded in the secondary market, gross of tax, and denominated in national currencies. All the yields are expressed in percentages per annum and are at annual 
Table 3: Overview of country sample

\begin{tabular}{llr} 
Zone & Countries & \# countries \\
\hline \multirow{2}{*}{$\begin{array}{l}\text { Peripheral euro area } \\
\text { Central euro area }\end{array}$} & Greece, Ireland, Italy, Portugal, Spain & 5 \\
& Austria, Belgium, Finland, France, Germany, Luxembourg, & 7 \\
Rest of EA19 & the Netherlands & 4 \\
Others & Cyprus, Latvia, Lithuania, Slovenia & 7 \\
& Bulgaria, Croatia, Czech Republic, Denmark, Hungary, & \\
& Sweden, United Kingdom
\end{tabular}

Total 23

frequency. ${ }^{7}$ Figure 3 shows the mean and variation in sovereign yield for our sample using a box plot.

Figure 3: Long term interest rates for EU countries

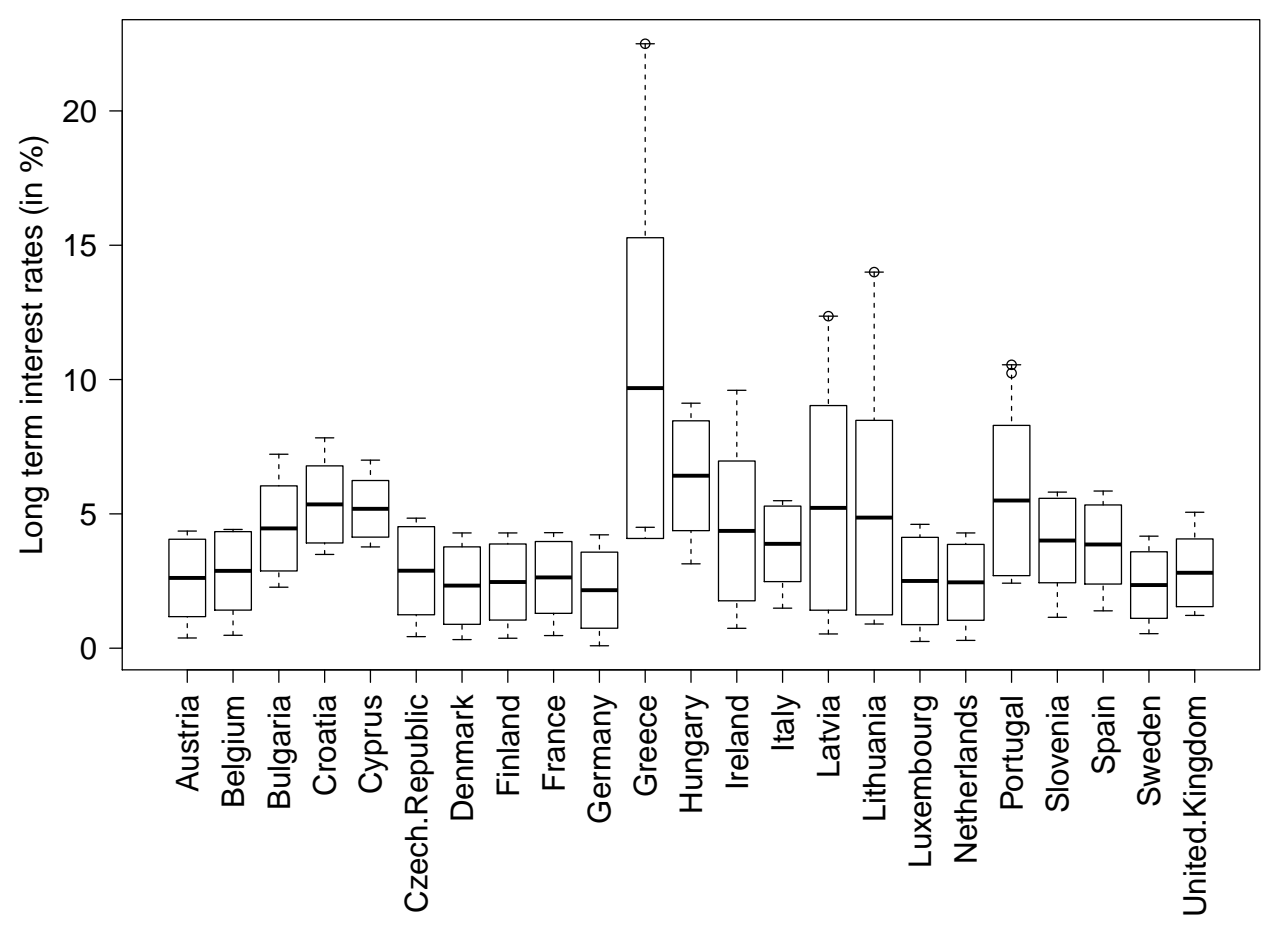

\subsection{Government support measures}

For the government support measures, we use the rich new dataset created by the European System of Central Banks (ESCB) Working Group on Government Finance Statistics

\footnotetext{
${ }^{7}$ For further details, refer to http://ec.europa.eu/eurostat/cache/metadata/en/irt_lt_mcby_esms.htm
} 
have provided the European Central Bank (ECB) with information on the financial interventions taken by their respective governments to stabilize the financial markets. This categorizes the variety of policymakers' fiscal responses to the crisis and offers the potential to estimate the effects of government interventions with more precision and with a better understanding of how the effects depend on the particular context.

Data on government support measures are collected from Eurostat. This data is available in the public domain since it is mandatory for national statisticians to inform the wider public of the direct fiscal impact of the bailout measures (decision by Eurostat in July 2009).

Figure 4 documents the cumulative net financial cost incurred by the European governments from the financial interventions to support financial institutions between 2007 and 2016 (both included). Most governments started providing financial assistance in 2008 (with the exception of the UK, where the government provided financial assistance in 2007 as well), while they suffered the worst losses between 2009 and 2013. The eastern European countries are latecomers to the crisis and their governments incurred major losses in 2014-15.

Figure 4: Cumulative realized cost of financial assistance - 2007:2016

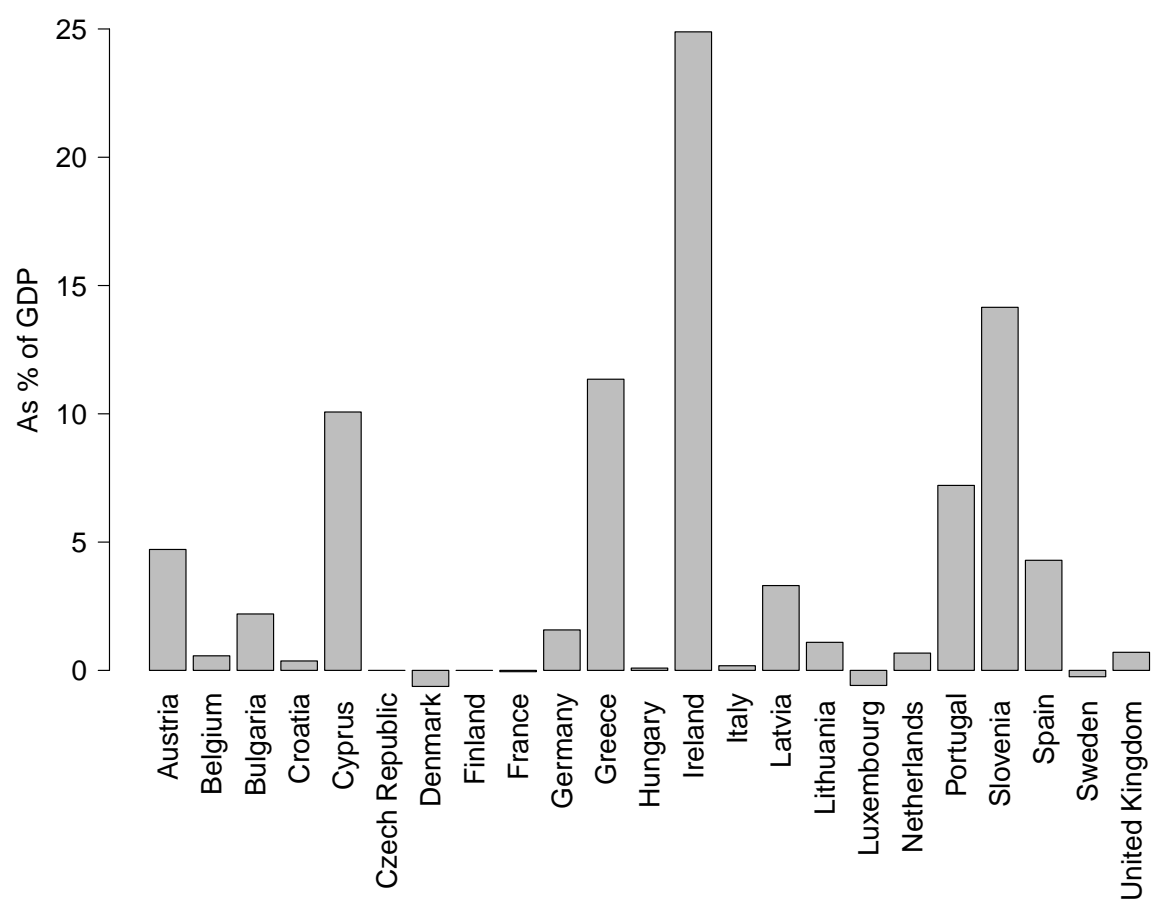

Note: The y-axis represents the direct cost in terms of 2008 GDP at market price for individual countries. Source: Eurostat. This data are presented at a yearly frequency from 2007 onwards for all EU28 countries. For a detailed breakdown of the data, see the compilation guide which is also available at the Eurostat website.

Ireland, Slovenia, Greece, Cyprus, and Portugal incurred the highest cost at $24.85 \%$, 
$14.15 \%, 11.35 \%, 10.07 \%$ and $7.21 \%$ of their 2008 GDP (at market price) respectively. On the other hand, France, Denmark, Luxembourg, and Sweden earned a small revenue from their financial assistance. ${ }^{8}$ Six out of the top seven countries with the highest costs (Ireland, Slovenia, Greece, Cyprus, Portugal, and Spain) needed external assistance from the IMF and the EU. Austria, Latvia, Bulgaria, Germany, and Lithuania also incurred net fiscal costs more than one percent of their GDP. On average, the countries suffered net losses of roughly $4 \%$ of their 2008 GDP (at market price) for their financial intervention.

Table 4 documents the maximum losses incurred by a particular country in a given year between 2007 and 2016. As can be seen, Ireland, Greece, Slovenia, and Cyprus suffered massive losses of 21.21\%, 10.76\%, 10.13\% and 8.91\% of yearly GDP in 2010, 2013, 2013 and 2014 respectively. Spain (2012), Portugal (2014), Latvia (2010) and Lithuania (2011) also suffered more than $2 \%$ of their yearly GDP in one particular year. Germany, Austria, and Bulgaria also suffered considerable losses at the peak of the crisis.

Figure 5 shows the evolution of government's yearly and cumulative financial cost together with the sovereign yield for selected countries. The bar represents the cumulative fiscal cost measure in 2008 GDP (at market price) terms. The solid black line represents the yearly cost in nominal terms while the broken red line represents the long-term interest rate. for convenience, only six countries have been plotted. Readers interested in other countries in our sample should refer to the online appendix at the author's website.

As can be seen, the cost of government intervention varies drastically across countries and across the year. For Spain, Germany and the UK, the cumulative cost is around $4.2 \%, 1.6 \%$ and $0.8 \%$ of GDP respectively. For Spain, the financial cost was highest in 2012, at roughly $3.6 \%$ of 2008 GDP. For Germany, the financial cost was highest in 2010 at roughly 1.5\% of GDP. Also notable is the fact that for some countries the net financial cost is positive. This is because the value of their financial asset holdings has increased over time or the guarantees they promised did not materialize but they collected the fees.

The sovereign yield in crisis-hit countries follows a very different path from the rest of the countries. For peripheral euro area countries, we see rising sovereign yield till 2012 and then a sudden reversal with the implementation of Outright Monetary Transaction program by the ECB. The pattern is repeated for Eastern European countries with a 2-3 year lag. For the rest of the countries, we see a continuous drop in sovereign yield across countries.

Figure 6 shows the evolution of total government liability (sum of gross debt and contingent guarantees) with the sovereign yield for selected countries. The red line represents total government liability (gross debt plus contingent guarantees) as \% of GDP while the blue line represents the long-term interest rate. ${ }^{9}$ As can be seen, total government liability has increased in almost all countries. In some countries, it has more than doubled since the onset of the global financial crisis, while in others, the change is relatively modest.

\footnotetext{
${ }^{8}$ This is because the value of their financial asset holdings has increased over time or the guarantees they promised did not materialize, but they collected the fees.

${ }^{9}$ For convenience, only six countries have been plotted. Readers interested in other countries in our sample should refer to the online appendix at the author's website.
} 
Table 4: Summary of net cost of financial assistance (2007:2016)

\begin{tabular}{|c|c|c|c|c|c|c|}
\hline Country & Average & $\mathrm{SD}$ & Maximum (Year) & 2nd Highest (Year) & 3rd Highest (Year) & Start Year \\
\hline Greece & 1.53 & 3.47 & $10.76(2013)$ & $2.80(2012)$ & $2.76(2015)$ & 2009 \\
\hline Ireland & 2.74 & 6.62 & $21.21(2010)$ & $3.71(2011)$ & $2.21(2009)$ & 2009 \\
\hline Italy & 0.02 & 0.06 & $0.20(2015)$ & $0.01(2013)$ & $0.01(2012)$ & 2009 \\
\hline Portugal & 0.73 & 0.94 & $2.95(2014)$ & $1.57(2015)$ & $1.23(2010)$ & 2008 \\
\hline Spain & 0.46 & 1.14 & $3.68(2012)$ & $0.33(2011)$ & $0.32(2013)$ & 2008 \\
\hline Austria & 0.43 & 0.51 & $1.60(2014)$ & $0.92(2009)$ & $0.64(2015)$ & 2008 \\
\hline Belgium & 0.05 & 0.20 & $0.58(2012)$ & $0.06(2016)$ & $0.06(2011)$ & 2008 \\
\hline France & -0.01 & 0.05 & $0.11(2012)$ & $0.0020(2016)$ & $0.0008(2015)$ & 2008 \\
\hline Germany & 0.16 & 0.40 & $1.28(2010)$ & $0.12(2009)$ & $0.12(2008)$ & 2008 \\
\hline Luxembourg & -0.04 & 0.10 & $0.19(2009)$ & $0.05(2008)$ & $0.01(2013)$ & 2008 \\
\hline Netherlands & 0.07 & 0.13 & $0.37(2009)$ & $0.18(2013)$ & $0.17(2010)$ & 2008 \\
\hline Bulgaria & 0.19 & 0.54 & $1.73(2014)$ & $0.21(2015)$ & - & 2014 \\
\hline Croatia & 0.04 & 0.06 & $0.16(2015)$ & $0.14(2010)$ & $0.07(2012)$ & 2010 \\
\hline Cyprus & 1.09 & 2.79 & $8.91(2014)$ & $1.38(2015)$ & $0.47(2016)$ & 2009 \\
\hline Hungary & 0.01 & 0.03 & $0.10(2016)$ & - & - & 2009 \\
\hline Latvia & 0.42 & 0.72 & $2.26(2010)$ & $0.98(2009)$ & $0.46(2012)$ & 2008 \\
\hline Lithuania & 0.15 & 1.06 & $2.84(2011)$ & $0.50(2013)$ & $0.12(2012)$ & 2010 \\
\hline Slovenia & 1.46 & 3.11 & $10.13(2013)$ & $1.79(2014)$ & $1.29(2015)$ & 2009 \\
\hline Denmark & -0.06 & 0.10 & $0.07(2011)$ & - & - & 2008 \\
\hline Sweden & -0.02 & 0.03 & $0.0004(2008)$ & - & - & 2008 \\
\hline United Kingdom & 0.07 & 0.18 & $0.47(2009)$ & $0.28(2008)$ & $0.07(2013)$ & 2007 \\
\hline
\end{tabular}

\subsubsection{Direct assistance (DirectAssistance)}

We consider all outstanding amount of actual liabilities of the general government which are reported as part of government intervention to support financial institutions as direct assistance. This measures the increase in liabilities arising from the government interventions to support financial institutions which are not contingent in nature. Apart from cases of direct borrowing, by convention, for the liabilities entries, it also accounts for the direct impact on government debt from activities which imply a transfer of cash from the government (e.g., transfer of cash relating to capital injections, loans granted, purchase of financial assets). Imputed financing costs are also included. In addition, liabilities not financed through a dedicated instrument ('indirect liabilities', i.e., liabilities deemed to be financed through the general financing policy of government) are also included. All liabilities are part of direct assistance as long as the corresponding asset (assumed to be financed by it) is held by a government unit. However, borrowing (with the intention to finance a support operation) in a financial period prior to the one when the operation actually takes place is not part of the targeted intervention before the actual support operation took place. Table 5 documents 
Figure 5: Yearly and cumulative realized cost of government interventions vs long term interest rate for selected countries - 2007:2016

(a) Italy

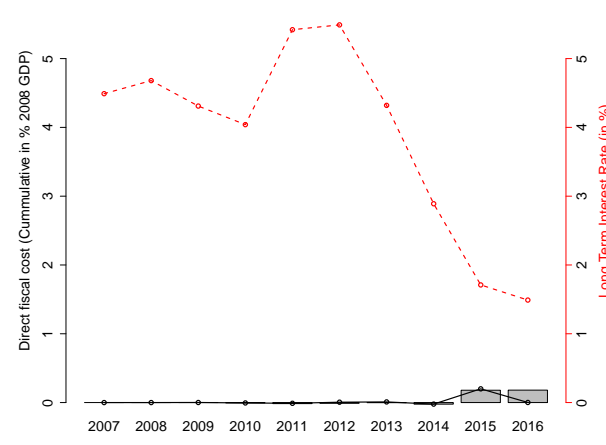

(c) France

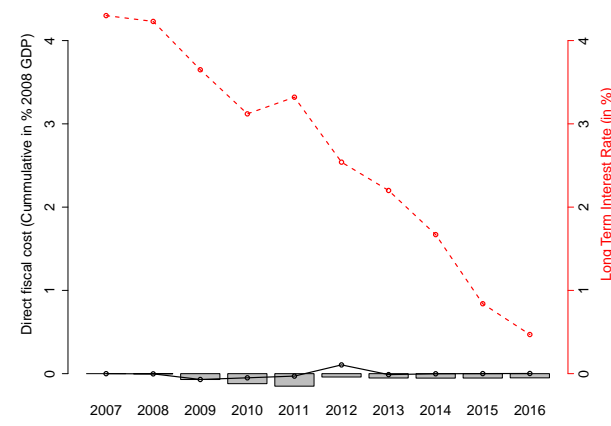

(e) Sweden

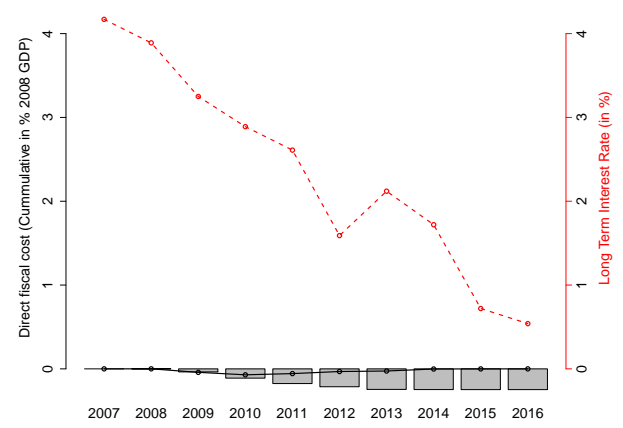

(b) Spain

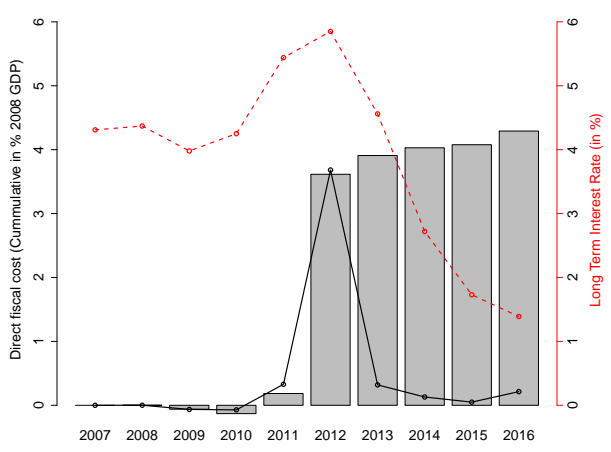

(d) Germany

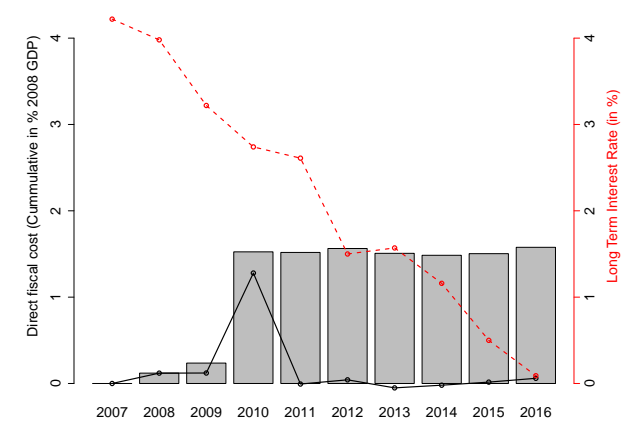

(f) United Kingdom

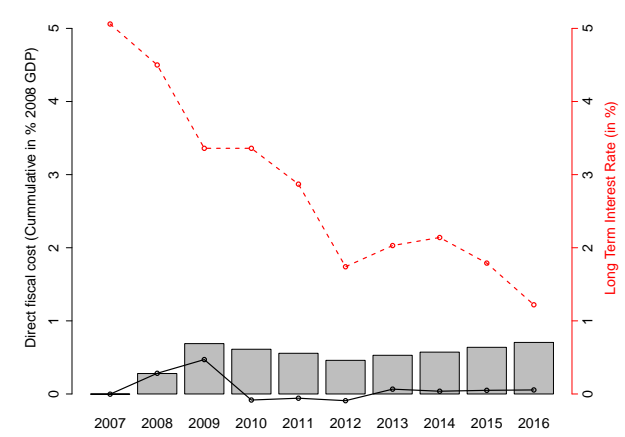

The bar represents the cumulative fiscal cost measure in 2008 GDP (at market price) terms. The solid black line represents the yearly cost in nominal terms while the broken red line represents the long-term interest rate. For convenience, only six countries have been plotted. Readers interested in other countries in our sample should refer to the online appendix at the author's website. 
Figure 6: Total government liability vs long term interest rate for selected countries - 2007:2016

(a) Italy

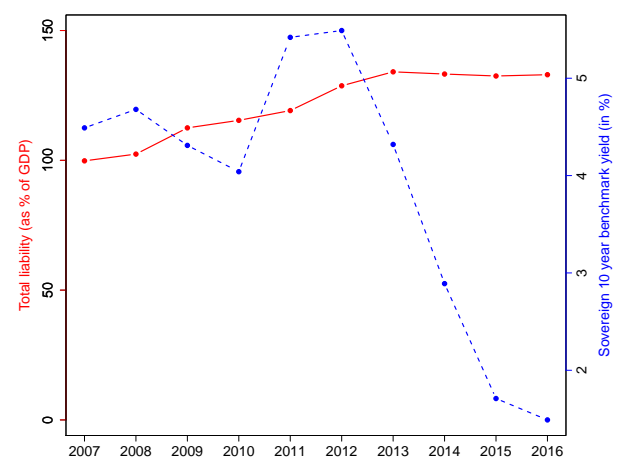

(c) France

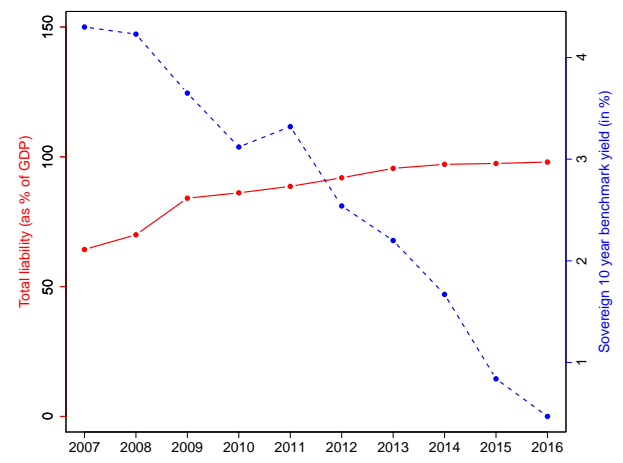

(e) Sweden

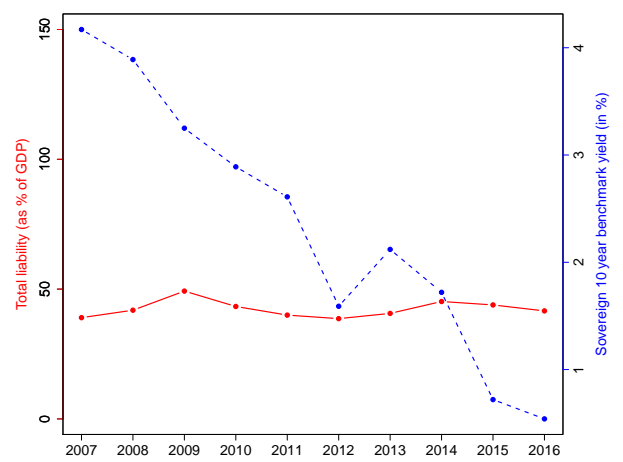

(b) Spain

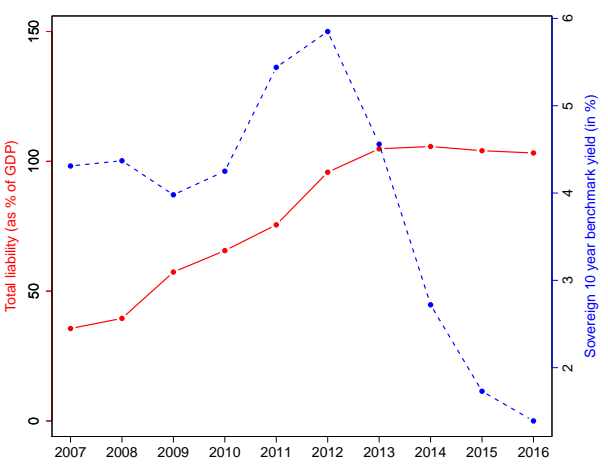

(d) Germany

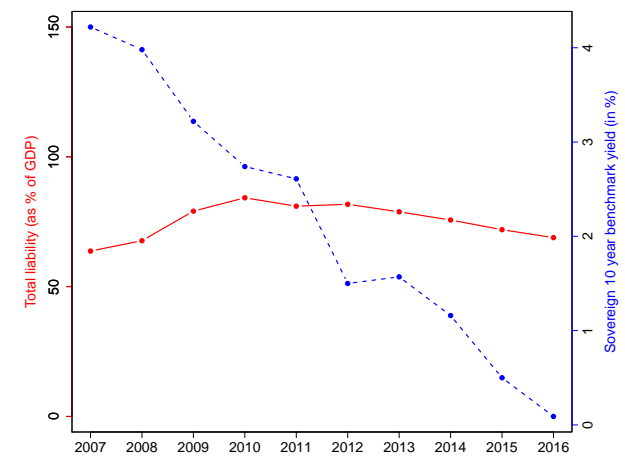

(f) United Kingdom

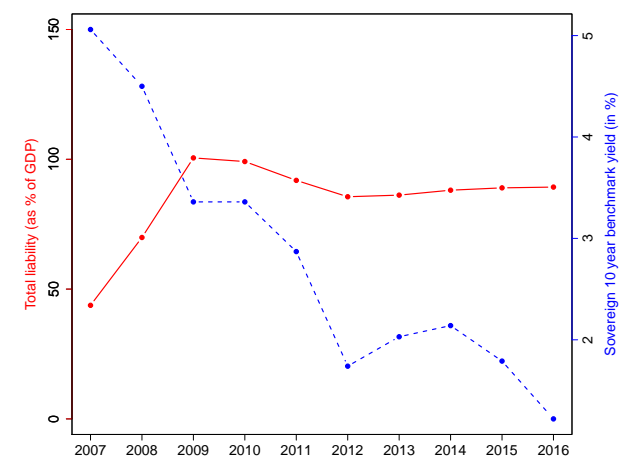

The red line represents the total government liability (gross debt plus contingent guarantees) as \% of GDP while the blue line represents the long term interest rate. For convenience, only six countries have been plotted. Readers interested in other countries in our sample should refer to the online appendix at the author's website.

the yearly evolution of DirectAssistance measure for individual countries across time. 
Table 5: Direct assistance

\begin{tabular}{lrrrrrrrrrr} 
Country & 2007 & 2008 & 2009 & 2010 & 2011 & 2012 & 2013 & 2014 & 2015 & 2016 \\
\hline & & & & & & & & & & \\
Austria & 0.00 & 0.31 & 7.93 & 7.50 & 6.57 & 5.91 & 5.09 & 8.43 & 10.81 & 9.55 \\
Belgium & 0.00 & 6.09 & 6.14 & 5.76 & 6.81 & 6.15 & 4.35 & 4.30 & 3.54 & 3.36 \\
Bulgaria & 0.00 & 0.00 & 0.00 & 0.00 & 0.00 & 0.00 & 0.00 & 2.81 & 2.40 & 0.56 \\
Croatia & 0.00 & 0.00 & 0.00 & 0.14 & 0.14 & 0.21 & 0.22 & 0.23 & 0.38 & 0.38 \\
Cyprus & 0.00 & 0.00 & 0.00 & 0.00 & 0.00 & 9.69 & 10.95 & 13.38 & 9.44 & 9.24 \\
Denmark & 0.00 & 0.24 & 4.35 & 3.89 & 3.11 & 2.51 & 2.27 & 0.41 & 0.13 & 0.12 \\
France & 0.00 & 0.57 & 0.30 & 0.04 & 0.00 & 0.12 & 0.13 & 0.13 & 0.13 & 0.13 \\
Germany & 0.00 & 2.04 & 3.85 & 11.88 & 10.82 & 10.70 & 8.80 & 8.14 & 7.38 & 7.20 \\
Greece & 0.00 & 0.00 & 1.67 & 1.52 & 2.47 & 19.15 & 24.66 & 23.00 & 25.43 & 24.31 \\
Hungary & 0.00 & 0.00 & 1.80 & 1.02 & 0.55 & 0.00 & 0.00 & 0.00 & 0.00 & 0.00 \\
Ireland & 0.00 & 0.00 & 6.33 & 27.84 & 48.68 & 46.59 & 40.10 & 31.28 & 22.90 & 21.19 \\
Italy & 0.00 & 0.00 & 0.26 & 0.25 & 0.16 & 0.16 & 0.25 & 0.07 & 0.09 & 0.17 \\
Latvia & 0.00 & 3.93 & 5.95 & 9.67 & 7.11 & 6.14 & 5.65 & 5.62 & 4.96 & 4.73 \\
Lithuania & 0.00 & 0.00 & 0.00 & 0.12 & 2.77 & 2.08 & 2.39 & 0.92 & 0.25 & 0.18 \\
Luxembourg & 0.00 & 6.56 & 6.76 & 6.22 & 5.79 & 5.67 & 5.38 & 5.00 & 4.80 & 4.72 \\
Netherlands & 0.00 & 12.77 & 9.40 & 8.37 & 6.92 & 6.41 & 6.71 & 5.55 & 4.36 & 3.21 \\
Portugal & 0.09 & 0.31 & 0.88 & 3.56 & 4.12 & 8.74 & 8.97 & 9.77 & 11.45 & 11.30 \\
Slovenia & 0.00 & 0.00 & 3.94 & 3.90 & 4.59 & 5.00 & 14.22 & 17.71 & 16.76 & 15.83 \\
Spain & 0.00 & 0.84 & 1.73 & 2.26 & 1.99 & 4.83 & 4.93 & 4.80 & 4.66 & 4.61 \\
Sweden & 0.00 & 0.07 & 0.17 & 0.16 & 0.15 & 0.15 & 0.00 & 0.00 & 0.00 & 0.00 \\
United Kingdom & 0.00 & 4.04 & 7.38 & 11.18 & 9.84 & 8.91 & 7.71 & 6.80 & 5.02 & 4.42 \\
\hline
\end{tabular}

As can be seen, the central euro area countries (Belgium, Germany, Luxembourg and the Netherlands) together with the UK intervened massively in the financial sector at the beginning of the crisis. On average, more than $6 \%$ of their GDP was used to stabilize their financial sector in 2008. In 2009, more countries intervened and the total support increased for almost all countries. The Netherlands, Austria and Ireland topped the chart with interventions between 6 and 10\% of their GDP. 2010 was the worst year for UK and Germany when the direct assistance reached more than 10\% of their GDP. For Ireland, 2010 saw the interventions increasing multi-fold to $27.84 \%$ of GDP. In Ireland it increased further over the years though it continued to subside for the rest of the euro area central countries.

For peripheral euro area countries, 2012 saw a sudden increase in their interventions when the focus started shifting from global financial crisis towards the sustainability of sovereign debt. Cyprus, Greece, Portugal, and Spain intervened with 9.69\%, 19.15\%, 8.74\% and 4.83\% of their 2012 GDP respectively to support their fragile financial institutions. These support measures have reached new heights over the years 2013-14. Most of these interventions are still in place at the time of writing. 


\subsubsection{Contingent guarantees (ContingentGuarantee)}

Contingent guarantees measure the guarantees granted by the general government to non-general government units which include the liquidity schemes and special purpose entities. The value includes active guarantees and does not include the announced ceilings for schemes. They also include guarantees on assets, whereby the government would incur liability in case of a call. Table 6 shows the contingent liabilities provided by the individual governments to support their financial institutions. These are not part of the current government debt but may contribute in the future. With regard to the coverage of data on contingent liabilities, it is important to note that general government guarantees on bank deposits are not included here, and nor are the central bank liquidity measures adopted during the financial crisis.

Table 6: Contingent guarantees

\begin{tabular}{lrrrrrrrrrr} 
Country & 2007 & 2008 & 2009 & 2010 & 2011 & 2012 & 2013 & 2014 & 2015 & 2016 \\
\hline Austria & 0.00 & 2.38 & 5.75 & 5.28 & 3.24 & 2.00 & 0.97 & 0.03 & 0.49 & 0.48 \\
Belgium & 0.00 & 10.23 & 17.79 & 15.29 & 12.39 & 15.24 & 11.56 & 9.38 & 7.68 & 8.68 \\
Bulgaria & 0.00 & 0.00 & 0.00 & 0.00 & 0.00 & 0.00 & 0.00 & 0.00 & 0.00 & 0.00 \\
Croatia & 0.00 & 0.00 & 0.00 & 0.00 & 0.00 & 0.00 & 0.00 & 0.00 & 0.00 & 0.00 \\
Cyprus & 0.00 & 0.00 & 11.94 & 15.35 & 14.03 & 5.13 & 5.51 & 5.68 & 5.64 & 0.00 \\
Czech Republic & 0.00 & 0.00 & 0.00 & 0.00 & 0.00 & 0.00 & 0.09 & 0.05 & 0.01 & 0.00 \\
Denmark & 0.00 & 0.00 & 3.09 & 11.18 & 9.00 & 3.73 & 0.49 & 0.26 & 0.00 & 0.00 \\
Finland & 0.00 & 0.06 & 0.00 & 0.00 & 0.00 & 0.00 & 0.00 & 0.00 & 0.00 & 0.00 \\
France & 0.00 & 1.96 & 5.16 & 4.52 & 3.41 & 2.42 & 3.25 & 2.20 & 1.83 & 1.98 \\
Germany & 0.00 & 2.59 & 6.46 & 3.21 & 2.29 & 1.82 & 1.30 & 0.76 & 0.73 & 0.57 \\
Greece & 0.00 & 0.78 & 2.36 & 24.7 & 32.75 & 28.3 & 28.31 & 28.61 & 25.37 & 2.23 \\
Hungary & 0.00 & 0.00 & 0.00 & 0.00 & 0.00 & 0.00 & 0.00 & 0.00 & 0.00 & 0.00 \\
Ireland & 0.00 & 187.65 & 165.3 & 93.67 & 79.91 & 65.07 & 30.34 & 12.25 & 4.31 & 1.44 \\
Italy & 0.00 & 0.00 & 0.00 & 0.00 & 2.67 & 5.31 & 5.09 & 1.44 & 0.39 & 0.38 \\
Latvia & 0.00 & 0.00 & 3.55 & 2 & 0.63 & 0.58 & 0.56 & 0.00 & 0.00 & 0.00 \\
Lithuania & 0.00 & 0.00 & 0.00 & 0.00 & 0.00 & 0.00 & 0.00 & 0.00 & 0.00 & 0.00 \\
Luxembourg & 0.00 & 4.66 & 4.09 & 3.32 & 3.19 & 5.01 & 4.86 & 4.38 & 3.53 & 4.04 \\
Netherlands & 0.00 & 0.43 & 12.87 & 6.33 & 5.31 & 2.82 & 1.66 & 0.00 & 0.00 & 0.00 \\
Portugal & 0.00 & 0.98 & 4.76 & 2.93 & 9 & 9.81 & 9.56 & 3.64 & 3.50 & 2.48 \\
Slovenia & 0.00 & 0.00 & 5.53 & 6.07 & 4.21 & 0.55 & 1.10 & 0.32 & 0.00 & 0.00 \\
Spain & 0.00 & 0.00 & 4.54 & 5.51 & 6.04 & 10.11 & 9.32 & 5.31 & 4.29 & 3.81 \\
Sweden & 0.00 & 4.37 & 8.23 & 5.01 & 2.48 & 0.82 & 0.24 & 0.02 & 0.00 & 0.00 \\
United Kingdom & 1.75 & 19.69 & 36.04 & 23.14 & 10.29 & 0.47 & 0.00 & 0.00 & 0.00 & 0.00 \\
\hline & & & & & & & & & &
\end{tabular}

As can be seen (Table 6), the contingent liabilities increased significantly in 2008 and 2009, before decreasing gradually in 2010 and 2011. This decrease mainly reflected reduced government exposure to guarantee schemes in Germany, Ireland, the Netherlands, and the UK. In 2012 we see new guarantees issued to financial institutions in Spain and Italy, while there was a decrease in contingent liabilities in several other euro area countries, mainly 
Ireland, France, and the Netherlands. In 2014, there were reductions in the amounts of guarantees in a number of countries, notably Ireland, Spain, and Italy. In 2015 and 2016, the decreasing trend continued due to reductions in the level of contingent liabilities mainly in Belgium, Germany (only 2016), Ireland and Italy.

Over 2007-16 the highest levels of contingent liabilities in relation to GDP were seen in Ireland. The peak was observed in 2008 as roughly 188\% of GDP. Seven members states (Belgium, Denmark, Greece, Spain, Cyprus, the Netherlands, and the UK) reported significant levels of contingent liabilities over the same period, ranging from $10 \%$ to about $37 \%$ of GDP. In 2016, in all EU Member States, the level of contingent liabilities has fallen below $2.5 \%$ of GDP.

Table 7 shows the episodes in which we observe the highest levels of sovereign guarantees together with the current state of these guarantees. For example, the average contingent liability provided by the Greek government is 17.36 percent of Greek GDP with a standard deviation of 13.97 percent. The highest contingent guarantee $32.75 \%$ of GDP was in the year 2011, followed by $28.72 \%$ in 2014. The first intervention was made in 2008 and continues even today, though the amount has fallen to $2.21 \%$ of GDP.

Table 7: Summary statistics: Contingent liabilities as percentage of GDP (2007:2016)

\begin{tabular}{|c|c|c|c|c|c|c|c|}
\hline Country & Average & $\mathrm{SD}$ & Maximum (Year) & 2nd Highest (Year) & 3rd Highest (Year) & Start Year & End Year \\
\hline Greece & 17.36 & 13.97 & $32.75(2011)$ & $28.72(2014)$ & $28.31(2013)$ & 2008 & Not yet \\
\hline Ireland & 63.99 & 68.37 & $187.65(2008)$ & $165.30(2009)$ & $93.67(2010)$ & 2008 & Not yet \\
\hline Italy & 1.53 & 2.11 & $5.31(2012)$ & $5.09(2013)$ & $2.67(2011)$ & 2011 & Not yet \\
\hline Portugal & 4.67 & 3.57 & $9.81(2012)$ & $9.56(2013)$ & $9.00(2011)$ & 2008 & Not yet \\
\hline Spain & 4.89 & 3.30 & $10.11(2012)$ & $9.32(2013)$ & $6.04(2011)$ & 2009 & Not yet \\
\hline Austria & 2.06 & 2.11 & $5.75(2009)$ & $5.28(2010)$ & $3.24(2011)$ & 2008 & Not yet \\
\hline Belgium & 10.83 & 5.00 & $17.79(2009)$ & $15.29(2010)$ & $15.24(2012)$ & 2008 & Not yet \\
\hline Finland & 0.01 & 0.02 & $0.06(2008)$ & $0.00(2007)$ & $0.00(2007)$ & 2008 & 2008 \\
\hline France & 2.67 & 1.48 & $5.16(2009)$ & $4.52(2010)$ & $3.41(2011)$ & 2008 & Not yet \\
\hline Germany & 1.97 & 1.87 & $6.46(2009)$ & $3.21(2010)$ & $2.59(2008)$ & 2008 & Not yet \\
\hline Luxembourg & 3.71 & 1.45 & $5.01(2012)$ & $4.86(2013)$ & $4.66(2008)$ & 2008 & Not yet \\
\hline Netherlands & 2.94 & 4.19 & $12.87(2009)$ & $6.33(2010)$ & $5.31(2011)$ & 2008 & 2013 \\
\hline Cyprus & 6.33 & 5.73 & $15.35(2010)$ & $14.03(2011)$ & $11.94(2009)$ & 2009 & 2015 \\
\hline Latvia & 0.73 & 1.17 & $3.54(2009)$ & $2.00(2010)$ & $0.63(2011)$ & 2009 & 2013 \\
\hline Czech Republic & 0.02 & 0.03 & $0.09(2013)$ & $0.05(2014)$ & $0.01(2015)$ & 2013 & 2015 \\
\hline Slovenia & 1.78 & 2.48 & $6.07(2010)$ & $5.53(2009)$ & $4.21(2011)$ & 2009 & 2014 \\
\hline Denmark & 2.78 & 4.12 & $11.17(2010)$ & $9.02(2011)$ & $3.72(2012)$ & 2009 & 2014 \\
\hline Sweden & 2.13 & 2.94 & $8.53(2009)$ & $5.33(2010)$ & 3.87 (2008) & 2008 & 2014 \\
\hline United Kingdom & 8.85 & 12.67 & $36.15(2009)$ & $23.06(2010)$ & $16.46(2008)$ & 2007 & 2012 \\
\hline
\end{tabular}

Note: In countries which are part of EU28 but are not mentioned here, no contingent liability was reported by the government. 


\subsection{Government liability excluding the financial assistance (GovLiabExclFinAsst)}

GovLiabExclFinAsst is calculated as the difference between the gross consolidated debt of the general government and liabilities arising out of direct assistance to support financial institutions. We can think of it as the current fiscal stance of a country net of the additional liabilities coming from the financial sector support measures. Note that it excludes the direct bailout cost arising from the direct assistance in the previous periods. However, it includes the financing cost arising due to direct assistance up until now. It also includes the cost net of guarantee fees due to contingent guarantees and the resulting financing cost due to increased deficit. ${ }^{10}$

GovLiabExclFinAsst includes not just the above-mentioned cost but also two additional losses. The first is the direct revenue losses which are due to the effect of financial crises on the country's tax system. The downward change in asset prices driven by financial instability lowers the direct taxes paid by households on wealth, direct taxes paid by corporations on assets and sales taxes. A reduction in real estate transactions (in price and volume), the slowdown of equity markets, decreases in dividends or the emergence of other depreciated assets all have a negative impact on fiscal revenues due to various tax rules.

Secondly, financial turmoil affects fiscal accounts indirectly through its impact on the real economy. Lower salaries and higher unemployment trigger a reduction in personal income tax and in social contributions but an increase in unemployment benefits. The negative wealth effect generated by the depreciation of financial and non-financial assets curbs consumption and investment. It thus reduces indirect tax revenues. Moreover, tighter credit conditions would further exacerbate this decrease. Finally, the subsequent increase in government debt would, in turn, affect the fiscal deficit via higher interest payments (for more detail, refer to Eschenbach and Schuknecht (2002), Maurer and Grussenmeyer (2015)). All in all, this variable must be interpreted with caution as it incorporates both - the primary and second-round effect of financial crises.

All other variables used in the empirical analysis are explained in detail in Appendix B. An overview of variable definitions and data sources is provided in Table 8, while Table B.1 shows the summary statistics.

\footnotetext{
${ }^{10}$ These detailed distinctions are important but are not relevant for our analysis, since we are not interested in estimating the fiscal cost related to financial crises.
} 
Table 8: Variable list

Sovereign risk measure

SovYield Sovereign's long term interest rate as used in Maastricht convergence criteria.

\section{Government support measures}

DirectAssistance Increase in the general government liabilities due of direct assistance.

ContingentGuarantee Contingent guarantees provided by the general government.

\section{Financial institutions characteristics}

SizeFI Size of the financial institutions relative to GDP.

ShareTop5CI Share of top 5 domestic credit institutions (CIs) in total CIs assets .

$\mathrm{HI}$

Herfindal index as a measure of asset concentration among domestic credit institutions.

\section{Country characteristics}

GDP

Gross domestic product.

Inflation

Annual inflation

Unemployment

GovDebt

Unemployment rate

Government consolidated gross debt.

GovLiabExclFinAsst Ratio of the difference between the government consolidated gross debt and liabilities arising from the government intervention to support financial institutions and GDP

\section{Institutional quality}

GovEff

Indicator of a country's perceived government effectiveness.
Annual

Annual

Annual

Annual

Annual

Annual

Annual

Annual

Annual

Annual

Annual

$$
\begin{array}{r}
\text { in \% } \\
\text { in \% } \\
\text { in Euro million } \\
\text { Percentage }
\end{array}
$$$$
\text { En Euro million }
$$

\section{Uncertainty measures}

\section{WUI \\ The World Uncertainty Index}

ESI

The Economic Sentiment Indicator
Annual average
Eurostat

Eurostat

Eurostat

SDW, ECB

SDW, ECB

SDW, ECB

Eurostat

Eurostat

Eurostat

Eurostat

Eurostat

\section{Dummy variables}

EUROAREA

A dummy variable that is one for euro area countries (EA-19) and zero otherwise.

GIIPS 


\section{Empirical analysis}

The empirical analysis starts by exploring whether there is a significant relationship between sovereign risk and financial support measure for our sample of countries. The analysis then explores the potential drivers of this relation.

\subsection{Financial assistance and sovereign risk}

Our first hypothesis addresses the general relationship between government intervention and sovereign yield. To that end, we run the following regression:

$$
\text { SovYield }_{i, t}=\beta_{0}+\beta_{1} \text { DirectAssistance }_{i, t}+\epsilon_{i, t}
$$

where $\operatorname{Sov} Y i e l d_{i, t}$ represents the 10-year benchmark government bond yield for country $i$ at time $t$, Dir Asst $t_{i, t}$ represents the direct assistance provided by country $i$ to their financial sector at time $t$ and $\epsilon_{i, t}$ the error term. The coefficient of interest is $\beta_{1}$, which shows the change in sovereign yield when direct assistance is increased by $1 \%$ of GDP, and we expect it to be positive and significant.

We run a similar regression specification for contingent guarantee to test the hypothesis that the relationship between contingent guarantee and sovereign risk is also positive and significant. Our regression model is as follows:

$$
\text { SovYield }_{i, t}=\beta_{0}+\beta_{1} \text { ContingentGuarantee }_{i, t}+\epsilon_{i, t}
$$

where $\operatorname{Sov} Y$ ield $d_{i, t}$ represents the 10-year benchmark government bond yield for country $i$ at time $t$, ContingentGuarante $e_{i, t}$ represents the contingent guarantees provided by country $i$ to their financial sector at time $t$ and $\epsilon_{i, t}$ the error term. The coefficient of interest $\beta_{1}$, which shows the change in sovereign yield when contingent assistance is increased by $1 \%$ of GDP.

Table 9 shows the regression results with heteroskedasticity-robust standard errors. Government interventions to support financial institutions clearly have an effect on the sovereign's creditworthiness. The significant positive coefficient of 0.06 and 0.029 implies that an additional percentage of GDP used to support financial institutions will increase the sovereign risk by 6 and 2.9 basis points depending on whether we are speaking of direct or contingent assistance. As can be noted, the deleterious effect of the contingent guarantee is roughly half of the effect of direct assistance.

\subsection{Baseline results}

To take stock of the government's existing debt, we modify the previous regression specification by adding the gross stock of debt which is not part of the direct intervention of government's support program (GovLiabExclFinAsst) together with the flow variables (direct assistance and contingent guarantees). To control for the different time period and its 
Table 9: Ordinary least square regression results

\begin{tabular}{lcc}
\hline \hline & \multicolumn{2}{c}{ Dependent variable: Sov Yield } \\
\cline { 2 - 3 } & $(1)$ & $(2)$ \\
\hline DirectAssistance & $0.060^{* *}$ & \\
& $(0.024)$ & \\
ContingentGuarantee & & $0.029^{* * *}$ \\
& & $(0.009)$ \\
Constant & & \\
& $3.679^{* * *}$ & $3.777^{* * *}$ \\
& $(0.210)$ & $(0.185)$ \\
\hline Observations & & 230 \\
$\mathrm{R}^{2}$ & 230 & 0.041 \\
Adjusted $\mathrm{R}^{2}$ & 0.026 & 0.037 \\
Residual Std. Error $(\mathrm{df}=228)$ & 0.022 & 2.683 \\
F Statistic $(\mathrm{df}=1 ; 228)$ & $6.096^{* *}$ & $9.732^{* * *}$ \\
\hline \hline Note: & ${ }^{*} \mathrm{p}<0.1 ;{ }^{* *} \mathrm{p}<0.05 ;{ }^{* * *} \mathrm{p}<0.01$ \\
\end{tabular}

effect on sovereign risk, we also add the year fixed effects. We run the following econometric specification:

$$
\begin{aligned}
\text { SovYield }_{i, t}= & \beta_{1} \text { GovLiabExclFinAsst }_{i, t} \\
& +\beta_{2} \text { DirectAssistance }_{i, t}+\beta_{3} \text { ContingentGuarantee }_{i, t} \\
& +\theta_{t}+\epsilon_{i, t}
\end{aligned}
$$

where $\theta_{t}$ captures the year fixed effect. SovYield ${ }_{i, t}$ represents the long term interest rate, GovLiabExclFinAsst ${ }_{i, t}$ is the gross consolidated government debt net of liability arising from government intervention (as \% of GDP), DirectAssistance $e_{i, t}$ is the liability (as \% of GDP) arising from direct interventions and ContingentGuarantee ${ }_{i, t}$ is the contingent guarantees (as \% of GDP) of country $i$ at time $t$. $\epsilon_{i, t}$ represents the error term. We cluster the standard errors at country level to allow for correlation of error terms within countries. The coefficient of interest are $\beta_{1}, \beta_{2}$ and $\beta_{3}$.

We consider three basic panel regression methods: the Pooled-OLS method, the fixedeffects (FE) method and the random effects (RE) model. Table 10 shows the regression results with heteroskedasticity-robust standard errors. Note that the coefficient shows the change in the sovereign's long-term interest rate when the level of government support goes up by one percent of GDP. In order to determine the empirical relevance of each of the potential methods for our panel data, we use several statistic tests. In particular, we test FE versus RE using the Hausman test statistic to test for non-correlation between the unobserved effect and the regressors (see Baltagi (2005), p. 66). To choose between pooledOLS and RE, we use Breusch and Pagan (1980)'s Lagrange multiplier test to test for the 
presence of an unobserved effect. Finally, we use the F test for fixed effects to test whether all unobservable individual effects are zero, in order to discriminate between pooled-OLS and RE. The results of these tests, (not show here to save space, but available from the authors upon request) show that the FE model is the relevant one in our case.

Table 10: Regression results: All components of government liability

\begin{tabular}{|c|c|c|c|}
\hline & \multicolumn{3}{|c|}{ Dependent variable: Sov Yield } \\
\hline & Pooled OLS & $F E$ & $R E$ \\
\hline & $(1)$ & $(2)$ & $(3)$ \\
\hline GovLiabExclFinAsst & $\begin{array}{l}0.017^{* *} \\
(0.008)\end{array}$ & $\begin{array}{l}0.027^{* *} \\
(0.013)\end{array}$ & $\begin{array}{c}0.022 \\
(0.014)\end{array}$ \\
\hline DirectAssistance & $\begin{array}{c}0.019 \\
(0.029)\end{array}$ & $\begin{array}{c}0.065^{*} \\
(0.035)\end{array}$ & $\begin{array}{c}0.042 \\
(0.030)\end{array}$ \\
\hline ContingentGuarantee & $\begin{array}{l}0.023^{* *} \\
(0.011)\end{array}$ & $\begin{array}{c}0.003 \\
(0.007)\end{array}$ & $\begin{array}{c}0.013^{*} \\
(0.007)\end{array}$ \\
\hline Constant & $\begin{array}{l}2.669^{* * *} \\
(0.487)\end{array}$ & & $\begin{array}{l}2.315^{\text {*** }} \\
(0.891)\end{array}$ \\
\hline Year FE & & Yes & \\
\hline Observations & 230 & 230 & 230 \\
\hline $\mathrm{R}^{2}$ & 0.088 & 0.195 & 0.128 \\
\hline Adjusted $\mathrm{R}^{2}$ & 0.076 & 0.151 & 0.117 \\
\hline F Statistic & $7.305^{* * *}(\mathrm{df}=3 ; 226)$ & $17.570^{* * *}(\mathrm{df}=3 ; 217)$ & $33.294^{* * *}$ \\
\hline
\end{tabular}

As can be seen, both stock and flow variables have a significant effect on sovereign yield although the magnitude differs considerably. The effect of contingent guarantee becomes insignificant while that of other government liabilities and direct assistance become significant. The effect of direct assistance is also more than twice that of other government liabilities. Time dummies are also important and the estimated coefficient change significantly. The explanatory power of the regression doubles in the case of FE and multiplies by 1.6 in the case of $\mathrm{RE}$ relative to the regression with the same controls, but without time dummies. Figure 7 plots the year dummy coefficients. As can be seen, the estimation identifies a general decline in the sovereign yield over the sample, that is intensified in December 2011 and February 2012 when two 3-year Long-Term Refinancing Operations (LTROs) were made available by the ECB to the banks.

\section{Robustness}

In this Section, we examined several robustness exercises. In particular, we assess whether the results are robust to different subsamples of countries, to the size and asset 
Figure 7: Time varying coefficient

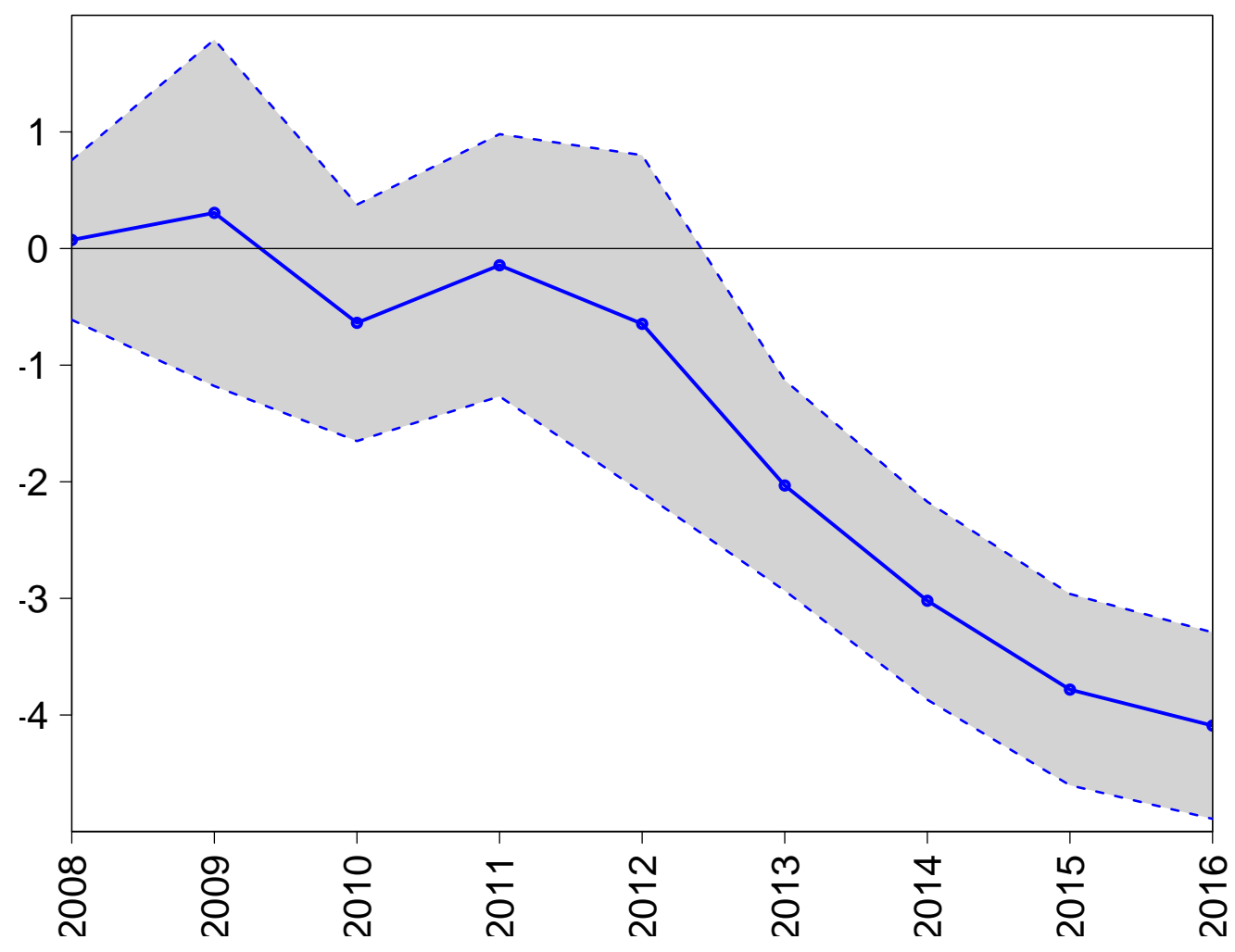

concentration in the financial sector, to the country characteristics and to uncertainty and market sentiment indicators. Going forward, all regression results show heteroskedasticityrobust standard errors.

\subsection{Effect of sample composition}

To control for the exogenous membership of different groups and understand the influence of a particular group, we subset our sample of countries in six different groups: (1) Full sample; (2) Non-euro area; (3) Euro area; (4) Euro area founders (EA12); ${ }^{11}$ (5) Central EA12 countries; and (6) Peripheral EA12 countries. We run the following regression model while controlling for different groups.

$$
\begin{aligned}
\text { SovYield }_{i, t}= & \beta_{1} \text { GovLiabExclFinAsst }_{i, t} \\
& +\beta_{2} \text { DirectAssistance }_{i, t}+\beta_{3} \text { ContingentGuarantee }_{i, t} \\
& +\theta_{t}+\mathbf{d}_{\text {memeber }=\mathbf{1}}+\epsilon_{i, t}
\end{aligned}
$$

\footnotetext{
${ }^{11}$ EA12 countries are Austria, Belgium, Finland, France, Germany, Greece, Ireland, Italy, Luxembourg, Portugal, Spain, The Netherlands. Central and peripheral countries are listed in Table 3.
} 
where the previous regression is extended by dummy variables $d$ which takes value 1 if the country $i$ belongs to a particular group. ${ }^{12}$

As can be seen (Table 11), the estimated effect of GovLiabExclFinAsst (our proxy of the fiscal stance of a country net of the additional liabilities coming from the financial sector support measures) is higher and highly significant for EA12 and peripheral countries with respect to the baseline regression results. Regarding the impact of the direct assistance, the results are much stronger for the Euro, EA12 and peripheral countries, but are negative for non-euro and central countries (although in the latter case it is statistically insignificant). As for the effect of contingent guarantee, it becomes statistically significant for the EA12, core and peripheral countries, and is higher in the case of the core countries.

Table 11: Effect of government liability on sovereign risk based on exogenous subset of countries

\begin{tabular}{|c|c|c|c|c|c|c|}
\hline & \multicolumn{6}{|c|}{ Dependent variable: SovYield } \\
\hline & (All) & (Euro) & (Non-euro) & $(\mathrm{EA} 12)$ & (Central) & (Peripheral) \\
\hline GovLiabExclFinAsst & $\begin{array}{l}0.027^{* *} \\
(0.013)\end{array}$ & $\begin{array}{c}0.029^{*} \\
(0.015)\end{array}$ & $\begin{array}{c}0.046^{*} \\
(0.025)\end{array}$ & $\begin{array}{l}0.045^{* * *} \\
(0.016)\end{array}$ & $\begin{array}{c}0.001 \\
(0.001)\end{array}$ & $\begin{array}{l}0.064^{* * *} \\
(0.017)\end{array}$ \\
\hline DirectAssistance & $\begin{array}{c}0.065^{*} \\
(0.035)\end{array}$ & $\begin{array}{c}0.092^{* *} \\
(0.042)\end{array}$ & $\begin{array}{c}-0.262^{* *} \\
(0.124)\end{array}$ & $\begin{array}{l}0.092^{* * *} \\
(0.034)\end{array}$ & $\begin{array}{c}-0.018 \\
(0.015)\end{array}$ & $\begin{array}{c}0.080^{*} \\
(0.047)\end{array}$ \\
\hline ContingentGuarantee & $\begin{array}{c}0.003 \\
(0.007)\end{array}$ & $\begin{array}{c}0.005 \\
(0.007)\end{array}$ & $\begin{array}{r}-0.067 \\
(0.055)\end{array}$ & $\begin{array}{c}0.014^{* *} \\
(0.006)\end{array}$ & $\begin{array}{l}0.037^{* * *} \\
(0.013)\end{array}$ & $\begin{array}{c}0.015^{* *} \\
(0.006)\end{array}$ \\
\hline Year FE & Yes & Yes & Yes & Yes & Yes & Yes \\
\hline Observations & 230 & 160 & 70 & 120 & 70 & 50 \\
\hline $\mathrm{R}^{2}$ & 0.195 & 0.241 & 0.476 & 0.467 & 0.333 & 0.446 \\
\hline Adjusted $\mathrm{R}^{2}$ & 0.151 & 0.180 & 0.366 & 0.407 & 0.192 & 0.266 \\
\hline
\end{tabular}

Notably, the sovereign risk is positively correlated with direct assistance in euro-area countries, while it is negatively correlated for non-euro countries. Increase in direct assistance by one percentage of GDP will lower the sovereign's long term borrowing cost by roughly 26 basis points for non-euro countries, but will increase the borrowing cost for euro area countries by nice basis points. This suggests that for the non-euro country, an increase in direct assistance reduces the risk of sovereign default. The effect is also three times larger than for euro area countries. This is interesting, as it highlights the challenges in fiscal consolidation for countries which are part of the monetary union.

\subsection{Effect of size and asset concentration in financial sector}

The debate about the financial sector regulations considers banks assets in proportion to GDP and the asset concentration within the financial sector as the key determinant of a country's ability to bail out its financial institutions. Thus, the presence of too many toobig-to-fail institutions or extreme concentration of assets restricts a sovereign's ability. We

\footnotetext{
${ }^{12}$ Although we run the Pooled OLS, FE and FE models, in Tables 11 to 15 we report only the results obtained using the FE model since this is the most appropriate in all cases.
} 
are particularly interested in assessing whether the relation between financial support and sovereign risk is stronger for countries with a large dependence on the financial sector and whether the relationship between financial support and sovereign risk is weaker for countries with a large concentration of assets in the financial sector. To that end, we use the following regression model:

$$
\begin{aligned}
\text { SovYield }_{i, t}= & \beta_{0}+\beta_{1} \text { GovLiabExclFinAsst }_{i, t} \\
& +\beta_{2} \text { DirectAssistance }_{i, t}+\beta 3 \text { ContingentGuarantee }_{i, t} \\
& +\gamma_{1} \text { SizeFI }_{\mathbf{i}, \mathbf{t}}+\gamma_{1} \text { ShareTop5FI }_{\mathbf{i}, \mathbf{t}}+\theta_{t}+\epsilon_{i, t}
\end{aligned}
$$

where the size of domestic financial institutions relative to GDP (SizeFI) is now included together with the asset concentration in the top five financial institutions (ShareTop5CI).

\begin{tabular}{|c|c|c|c|c|}
\hline & \multicolumn{4}{|c|}{ Dependent variable: SovYield } \\
\hline & $(1)$ & $(2)$ & $(3)$ & $(4)$ \\
\hline GovLiabExclFinAsst & $\begin{array}{c}0.027^{* *} \\
(0.013)\end{array}$ & $\begin{array}{l}0.032^{* * *} \\
(0.012)\end{array}$ & $\begin{array}{l}0.025^{* *} \\
(0.011)\end{array}$ & $\begin{array}{l}0.031^{\text {*** }} \\
(0.010)\end{array}$ \\
\hline DirectAssistance & $\begin{array}{c}0.065^{*} \\
(0.035)\end{array}$ & $\begin{array}{c}0.073^{* *} \\
(0.035)\end{array}$ & $\begin{array}{c}0.071^{* *} \\
(0.028)\end{array}$ & $\begin{array}{c}0.078^{* *} \\
(0.031)\end{array}$ \\
\hline ContingentGuarantee & $\begin{array}{c}0.003 \\
(0.007)\end{array}$ & $\begin{array}{c}0.008 \\
(0.007)\end{array}$ & $\begin{array}{c}0.005 \\
(0.007)\end{array}$ & $\begin{array}{c}0.009 \\
(0.006)\end{array}$ \\
\hline SizeFI & & $\begin{array}{c}-0.661^{* * *} \\
(0.221)\end{array}$ & & $\begin{array}{c}-0.687^{\text {*** }} \\
(0.185)\end{array}$ \\
\hline ShareTop5CI & & & $\begin{array}{c}0.038^{* *} \\
(0.018)\end{array}$ & $\begin{array}{c}0.029^{*} \\
(0.015)\end{array}$ \\
\hline Year FE & Yes & Yes & Yes & Yes \\
\hline Observations & 230 & 212 & 219 & 207 \\
\hline $\mathrm{R}^{2}$ & 0.195 & 0.328 & 0.274 & 0.393 \\
\hline Adjusted $\mathrm{R}^{2}$ & 0.151 & 0.284 & 0.228 & 0.349 \\
\hline
\end{tabular}
All other variables are defined as in the previous regressions.

Table 12: Results: Effect of financial sector

Table 12 shows the results when year fixed effects are included. As can be seen, we find negative and positive significant coefficients for SizeFI and ShareTop5CI respectively. These results suggest that, controlling for government interventions, higher dependence on the financial sector negatively influences the sovereign risk, while asset concentration in financial sector has a positive impact on the sovereign risk. When we run regression substituting ShareTop5CI with the Herfindahl index $(H I)$, the effect vanishes. The results 
suggest that countries where financial institutions had bigger assets, offered a lower cost of borrowing to the sovereign and were more resilient in the current crisis. Note that the effect of direct assistance is consistently significant and is within a narrow range for the different specification. Contingent guarantees, on the other hand, had no significant effect on the sovereign's borrowing conditions or funding costs.

\subsection{Effect of country characteristics}

Several different country characteristics may be drivers of the sovereign-bank nexus (see Attinasi et al. (2009)). First, we consider the size of a country (proxied by GDP), which is linked with its relative importance in the global market. Second, in view of Mody (2009)'s argument that countries' sensitivity to the financial crisis is more pronounced the greater the loss of their growth potential and competitiveness, we include instruments that measure these features. The unemployment rate is the variable used to capture the country's growth potential, whilst the inflation rate is used as a proxy of the appreciation of the real exchange rate and, thus, the country's loss of competitiveness. An increase in either unemployment or inflation represents a deterioration of growth potential and competitiveness; therefore, it should augment sovereign yield.

Finally, we consider a country's perceived governance quality, as reflected in the government effectiveness indicator provided by the World Bank. Investigating this indicator captures the idea that country governance may be related to government actions during the financial crisis (see Schnabel and Schüwer (2016)), and therefore affect the government's ability to intervene. To examine whether the relation between government support and sovereign risk is modified by the country characteristics, our regression model takes the following form:

$$
\begin{aligned}
\text { SovYield }_{i, t}= & \beta_{0}+\beta_{1} \text { GovLiabExclFinAsst }_{i, t} \\
& +\beta_{2} \text { DirectAssistance }_{i, t}+\beta_{3} \text { ContingentGuarantee }_{i, t} \\
& +\gamma_{1} \mathbf{l n}\left(\mathbf{G D P}_{\mathbf{i}, \mathbf{t}}\right)+\gamma_{2} \text { Inflation }_{\mathbf{i}, \mathbf{t}}+\gamma_{3} \text { Unemployment }_{\mathbf{i}, \mathbf{t}} \\
& +\gamma_{4} \text { GovEff }_{\mathbf{i}, \mathbf{t}}+\theta_{t}+\epsilon_{i, t}
\end{aligned}
$$

where $G D P_{i, t}$ and GovE $f f_{i, t}$ stand for Gross Domestic Product and perceived government effectiveness of country $i$ in period $t$. All other variables are defined as in the previous regressions.

Table 13 shows the coefficient with the year fixed effects. As can be seen, the estimated coefficient for $\log (\mathrm{GDP})$ is negative and highly significant suggesting that an increase in aggregate economic activity reduces sovereign yields. The inclusion of $\log$ (GDP) reduces the effect of the direct assistance and marginally raises the effect of the contingent guarantee. As regards inflation, as expected we obtain a positive and highly significant coefficient. The remaining results are very similar to the main specification. When controlling for unemployment, as expected we obtain a positive and highly significant coefficient for this variable, while the rest of the variables become statistically insignificant. Turning to the case of the role of perceived government effectiveness, we obtain a negative and highly significant 
impact of this variable on sovereign yield and a significant increase of the estimated effect of the direct assistance, and a marginal rise in the estimated effect of the contingent guarantee. Finally, controlling together for the four country characteristics, we obtain a similar effect for the contingent guarantee and a reduction of the estimated effect of the direct assistance with respect to the baseline specification.

Table 13: Effect of macroeconomic variables

\begin{tabular}{|c|c|c|c|c|c|c|}
\hline & \multicolumn{6}{|c|}{ Dependent variable: SovYield } \\
\hline & (1) & $(2)$ & $(3)$ & $(4)$ & $(5)$ & (6) \\
\hline GovLiabExclFinAsst & $\begin{array}{l}0.027^{* *} \\
(0.013)\end{array}$ & $\begin{array}{l}0.046^{* * *} \\
(0.009)\end{array}$ & $\begin{array}{c}0.028^{* *} \\
(0.013)\end{array}$ & $\begin{array}{c}0.012 \\
(0.008)\end{array}$ & $\begin{array}{c}0.017^{*} \\
(0.010)\end{array}$ & $\begin{array}{l}0.026^{* * *} \\
(0.006)\end{array}$ \\
\hline DirectAssistance & $\begin{array}{c}0.065^{*} \\
(0.035)\end{array}$ & $\begin{array}{c}0.047^{* *} \\
(0.020)\end{array}$ & $\begin{array}{c}0.069^{* *} \\
(0.035)\end{array}$ & $\begin{array}{c}0.038 \\
(0.024)\end{array}$ & $\begin{array}{l}0.080^{* * *} \\
(0.027)\end{array}$ & $\begin{array}{l}0.044^{* * *} \\
(0.014)\end{array}$ \\
\hline ContingentGuarantee & $\begin{array}{c}0.003 \\
(0.007)\end{array}$ & $\begin{array}{c}0.004 \\
(0.006)\end{array}$ & $\begin{array}{c}0.007 \\
(0.007)\end{array}$ & $\begin{array}{r}-0.002 \\
(0.005)\end{array}$ & $\begin{array}{c}0.007 \\
(0.007)\end{array}$ & $\begin{array}{c}0.004 \\
(0.005)\end{array}$ \\
\hline $\log (\mathrm{GDP})$ & & $\begin{array}{c}-0.907^{* * *} \\
(0.146)\end{array}$ & & & & $\begin{array}{c}-0.544^{* * *} \\
(0.109)\end{array}$ \\
\hline Inflation & & & $\begin{array}{l}0.255^{* * *} \\
(0.094)\end{array}$ & & & $\begin{array}{c}0.121^{*} \\
(0.067)\end{array}$ \\
\hline Unemployment & & & & $\begin{array}{l}0.287^{* * *} \\
(0.093)\end{array}$ & & $\begin{array}{l}0.176^{* * *} \\
(0.064)\end{array}$ \\
\hline Government Effectiveness & & & & & $\begin{array}{c}-2.153^{* * *} \\
(0.418)\end{array}$ & $\begin{array}{c}-0.754^{* * *} \\
(0.254)\end{array}$ \\
\hline Year FE & Yes & Yes & Yes & Yes & Yes & Yes \\
\hline Observations & 230 & 230 & 230 & 230 & 230 & 230 \\
\hline $\mathrm{R}^{2}$ & 0.195 & 0.464 & 0.220 & 0.445 & 0.437 & 0.607 \\
\hline Adjusted $\mathrm{R}^{2}$ & 0.151 & 0.432 & 0.173 & 0.412 & 0.403 & 0.577 \\
\hline
\end{tabular}

In summary, in line with our expectations, we find a significant negative relationship between country GDP and sovereign yield. We also found that an increase in either unemployment or inflation - a deterioration of growth potential and competitiveness - increases the sovereign yield. The effect is far stronger for the case of unemployment than for inflation. The effect of government effectiveness is significantly negative, which means that the sovereign risk is lower for countries with high perceived government effectiveness.

\subsection{Effect of uncertainty and market sentiment}

The sovereign debt crisis in Europe has attributed increasing importance to uncertainty and to variables reflecting investment confidence conditions and perceptions for the upcom- 
ing economic activity (see, e.g. Georgoutsos and Migiakis (2013)). To evaluate the effect of such variables, we use World Uncertainty Index (WUI) and Economic Sentiment Indicators (ESI). The WUI is an index of economic uncertainty for 143 countries constructed using frequency counts of "uncertainty" (and its variants) in the quarterly Economist Intelligence Unit (EIU) country reports. ${ }^{13}$ As increased uncertainty is usually accompanied by an increase in risk components and, thus, leads to increases in bond yields, we expect a positive sign for the respective coefficient. As for the ESI, it is a composite indicator published by Eurostat and is usually employed to gauge economic agents' perceptions of future economic activity. It seems reasonable to expect it will have a negative relationship with yields, since increase in the ESI may lead to a rise in investor confidence in the economy's potential for growth. ${ }^{14}$

Table 14: The role of macroeconomic uncertainty

\begin{tabular}{|c|c|c|c|c|}
\hline & \multicolumn{4}{|c|}{ Dependent variable: SovYield } \\
\hline & $(1)$ & $(2)$ & $(3)$ & $(4)$ \\
\hline GovLiabExclFinAsst & $\begin{array}{l}0.027^{* *} \\
(0.013)\end{array}$ & $\begin{array}{c}0.025^{*} \\
(0.015)\end{array}$ & $\begin{array}{c}0.021^{*} \\
(0.011)\end{array}$ & $\begin{array}{c}0.017 \\
(0.012)\end{array}$ \\
\hline DirectAssistance & $\begin{array}{c}0.065^{*} \\
(0.035)\end{array}$ & $\begin{array}{c}0.062^{*} \\
(0.034)\end{array}$ & $\begin{array}{l}0.074^{* *} \\
(0.033)\end{array}$ & $\begin{array}{c}0.075^{* *} \\
(0.035)\end{array}$ \\
\hline ContingentGuarantee & $\begin{array}{c}0.003 \\
(0.007)\end{array}$ & $\begin{array}{c}0.004 \\
(0.007)\end{array}$ & $\begin{array}{r}-0.008 \\
(0.005)\end{array}$ & $\begin{array}{r}-0.008 \\
(0.005)\end{array}$ \\
\hline WUI & & $\begin{array}{c}-0.043 \\
(1.649)\end{array}$ & & $\begin{array}{r}-0.734 \\
(1.436)\end{array}$ \\
\hline ESI & & & $\begin{array}{c}-0.144^{* * *} \\
(0.044)\end{array}$ & $\begin{array}{c}-0.162^{* * *} \\
(0.052)\end{array}$ \\
\hline Year FE & Yes & Yes & Yes & Yes \\
\hline Observations & 230 & 210 & 230 & 210 \\
\hline $\mathrm{R}^{2}$ & 0.195 & 0.173 & 0.303 & 0.292 \\
\hline Adjusted $\mathrm{R}^{2}$ & 0.151 & 0.118 & 0.262 & 0.241 \\
\hline
\end{tabular}

Table 14 shows the regression result. All specifications contain year fixed effects. When controlling for economic uncertainty we obtain a negative, not statistically significant coefficient, while the remaining results are very similar to the main specification. Regarding ESI,

\footnotetext{
${ }^{13} \mathrm{http}: / /$ www.policyuncertainty.com/wui_quarterly.html

${ }^{14}$ Furthermore, results in Laborda and Olmo (2014) suggest that market sentiment helps to explain systematic deviations in bond prices that are related to waves of market sentiment such as the flight-to-quality phenomenon between stocks and bonds.
} 
we obtain as expected a negative and highly significant coefficient for this variable, while the rest of variables become statistically insignificant; there is a significant increase of the estimated effect of the direct assistance and a change of sign in the estimated effect of the contingent guarantee, the latter not being statistically significant. Finally, when controlling for both uncertainty variables together, we obtain an increase in the positive and statistically significant estimated effect of the direct assistance and a negative and insignificant effect for the contingent guarantee with respect to the baseline specification.

As can be seen, the effect of direct assistance is consistently significant and is within a narrow range for the different specification. On the other hand, contingent guarantees are consistently insignificant. The coefficient of uncertainty indicator is insignificant while the economic sentiment is significantly negative. These results give robust evidence of the effect of direct assistance on the sovereign's yield. They also suggest that the market perception of future economic activities strongly influences the sovereign's current borrowing prospects.

\subsection{Combined analysis}

So far, we have tested the effect of different potential drivers of the sovereign risk in separate regressions. Next, we run analyses where measures for financial sector characteristics and country characteristics are used jointly as explanatory variables. Since the euro area members have significantly different institutional structures, we explore this further by extending the regression specification by the dummy variables euro ${ }_{i}$. The variable euro has a value of 1 for all euro area countries and zero otherwise.

Summing up (Table 15), several coefficients become less significant or insignificant for the combined analysis relative to our previous results. Due to multicollinearity, this is not unexpected. However, for the remaining, the coefficients point toward the same relations identified before. In particular, the results of this combined analysis are consistent with our results: (1) An additional percentage of GDP in direct assistance increases the sovereign yield by 6.2 basis points; (2) An additional percentage of GDP as contingent guarantee has no significant effect on sovereign yield; (3) Size of the country, perceived government effectiveness and better economic sentiments negatively affect the sovereign yield; (4) Rising unemployment, rising inflation, and increasing uncertainty positively affect sovereign yield; and (5) Membership of the euro area lowers the sovereign yield by roughly 85 basis points.

\section{Conclusion}

In this paper, we analyze the effect of government interventions to support financial institutions on the sovereign risk profile. To this end, we classify all government interventions into two broad categories: (1) Direct assistance, which increase the government's financing need immediately; and (2) Contingent guarantees, which have no direct impact immediately but increase the funding requirement as and when loss materializes.

Our findings suggest that even though both forms of financial assistance are temporary in nature, direct assistance is significantly more expensive. This is so because the provision of direct assistance requires immediate disbursement of the resources available to the government, which in turn are determined by the sovereign's current risk profile. In times of crisis, 
Table 15: Regression results: Combined analysis

\begin{tabular}{|c|c|c|c|}
\hline & \multicolumn{3}{|c|}{ Dependent variable: SovYield } \\
\hline & $(1)$ & $(2)$ & $(3)$ \\
\hline GovLiabExclFinAsst & $\begin{array}{c}0.027^{* *} \\
(0.013)\end{array}$ & $\begin{array}{l}0.025^{* * *} \\
(0.007)\end{array}$ & $\begin{array}{l}0.028^{* * *} \\
(0.007)\end{array}$ \\
\hline DirectAssistance & $\begin{array}{c}0.065^{*} \\
(0.035)\end{array}$ & $\begin{array}{l}0.049^{* * *} \\
(0.016)\end{array}$ & $\begin{array}{l}0.062^{\text {*** }} \\
(0.015)\end{array}$ \\
\hline ContingentGuarantee & $\begin{array}{c}0.003 \\
(0.007)\end{array}$ & $\begin{array}{r}-0.003 \\
(0.004)\end{array}$ & $\begin{array}{r}-0.003 \\
(0.003)\end{array}$ \\
\hline SizeFI & & $\begin{array}{r}-0.008 \\
(0.134)\end{array}$ & $\begin{array}{r}-0.077 \\
(0.138)\end{array}$ \\
\hline ShareTop5CI & & $\begin{array}{c}0.009 \\
(0.008)\end{array}$ & $\begin{array}{c}0.010 \\
(0.007)\end{array}$ \\
\hline $\log (\mathrm{GDP})$ & & $\begin{array}{c}-0.588^{* * *} \\
(0.201)\end{array}$ & $\begin{array}{c}-0.548^{* * *} \\
(0.184)\end{array}$ \\
\hline Inflation & & $\begin{array}{c}0.119^{*} \\
(0.062)\end{array}$ & $\begin{array}{c}0.123^{*} \\
(0.066)\end{array}$ \\
\hline Unemployment & & $\begin{array}{c}0.139^{* *} \\
(0.055)\end{array}$ & $\begin{array}{l}0.149^{* * *} \\
(0.050)\end{array}$ \\
\hline Government Effectiveness & & $\begin{array}{c}-0.891^{* * *} \\
(0.221)\end{array}$ & $\begin{array}{c}-0.701^{\text {*** }} \\
(0.219)\end{array}$ \\
\hline WUI & & $\begin{array}{l}2.194^{* *} \\
(0.855)\end{array}$ & $\begin{array}{c}1.353^{*} \\
(0.767)\end{array}$ \\
\hline ESI & & $\begin{array}{c}-0.088^{* *} \\
(0.036)\end{array}$ & $\begin{array}{c}-0.101^{\text {*** }} \\
(0.034)\end{array}$ \\
\hline EUROAREA & & & $\begin{array}{c}-0.853^{* *} \\
(0.335)\end{array}$ \\
\hline Year FE & Yes & Yes & Yes \\
\hline Observations & 230 & 194 & 194 \\
\hline $\mathrm{R}^{2}$ & 0.195 & 0.658 & 0.675 \\
\hline Adjusted $\mathrm{R}^{2}$ & 0.151 & 0.618 & 0.635 \\
\hline
\end{tabular}


if a large amount needs to be transferred to the banking sector and the government's fiscal space is limited, direct intervention will have a direct detrimental effect on the sovereign's solvency and will increase its funding costs. We also found that the contingent guarantee does not affect significantly the sovereign risk, possibly because contingent guarantees (1) do not increase the funding requirement immediately, and (2) indirectly influence both banking and sovereign risk; since the likelihood of a banking crisis and that of a sovereign default affect one another, the resulting gain might offset the increased cost (see Leonello (2017)).

Overall, the analysis suggests that policies addressing the design of financial intervention schemes and their funding are important for limiting the sovereign's own fragility (see Bova et al. (2016)). Since the government's budget is limited, and both the banks and the government are fragile, it is of utmost importance to address the financial assistance design and its funding while limiting the impact on the sovereign's own risk. It also provides support to the argument that the credibility and effectiveness of the guarantees are intertwined with the sovereign funding risk (see König et al. (2014), Leonello (2017)).

This paper could be extended in a number of interesting directions. At this stage, we assume that direct assistance and contingent guarantees are interchangeable. This assumption may not be justified. In the future, we hope to be able to understand the components of financial interventions that cannot be interchanged, and thus have more precise estimates. Another possible extension would be to consider the role of a supranational authority providing the guarantees instead of the national government. This analysis might provide some interesting insights into the introduction of pan-European insurance or bank resolution schemes. Finally, we would like to understand the potential distortions in bank's behavior associated with different interventions.

\section{Acknowledgment}

This work was supported by the Spanish Ministry of Economy and Competitiveness [grant ECO2016-76203-C2-2-P]. Simon Sosvilla-Rivero and Manish K. Singh thank the hospitality provided by the Department of Economics during a research visit at the University of Barcelona. The opinions expressed in this paper are those of the authors, and they do not reflect in any way those of the institutions to which they are affiliated. Responsibility for any remaining errors rests with the authors. 


\section{References}

Arslanalp, S., Liao, Y., 2014. Banking sector contingent liabilities and sovereign risk. Journal of Empirical Finance 29, 316-330.

Attinasi, M.G., Checherita, C., Nickel, C., 2009. What explains the surge in Euro area sovereign spreads during the financial crisis. European Central Bank, Working Paper Series 1131.

Baltagi, B.H., 2005. Econometric analysis of panel data. Third Edition. John Wiley \& Sons, New York.

Bova, E., Ruiz-Arranz, M., Toscani, F., , Ture, H.E., 2016. The fiscal costs of contingent liabilities: A new dataset. IMF Working Paper 16/14.

Bresciani, M.V., Cossaro, L., 2016. A balance sheet approach to general government finance: The legacy of the crisis in selected euro area countries. Paper presented at the 13th Euroframe Conference on Economic Policy Issues in the European Union, Utrecht, The Netherlands.

Breusch, T.S., Pagan, A.R., 1980. The lagrange multiplier test and its applications to model specification in econometrics. Review of Economic Studies 47, 239-253.

Correa, R., Lee, K., Sapriza, H., Suarez, G.A., 2014. Sovereign credit risk, banks' government support, and bank stock returns around the world. Journal of Money, Credit and Banking 46, 93-121.

Eschenbach, F., Schuknecht, L., 2002. The fiscal cost of financial instability revisited. Working Paper No. 191, European Central Bank, Frankfurt upon Main.

Georgoutsos, D.A., Migiakis, P.M., 2013. Heterogeneity of the determinants of Euro-area sovereign bond spreads: What does it tell us about financial stability? Journal of Banking and Finance 37, 4650-4664.

Honohan, P., Klingebiel, D., 2003. The fiscal cost implications of an accommodating approach to banking crises. Journal of Banking and Finance 27, 1539-1560.

Hüttl, P., Schoenmaker, D., 2016. Fiscal capacity to support large banks. Bruegel Policy Contribution, Issue No. 17.

Kaufmann, D., Kraay, A., Mastruzzi, M., 2010. The worldwide governance indicators: Methodology and analytical issues. World Bank Policy Research Working Paper No. 5430.

König, P., Anand, K., Heinemann, F., 2014. Guarantees, transparency and the interdependency between sovereign and bank default risk. Journal of Banking and Finance 45, 321-337.

Laborda, R., Olmo, J., 2014. Investor sentiment and bond risk premia. Journal of Financial Markets 18, 206-233.

Langfield, S., Pagano, M., 2016. Bank bias in Europe: effects on systemic risk and growth. Economic Policy , 51-106.

Leonello, A., 2017. Government guarantees and the two-way feedback between banking and sovereign debt crises. European Central Bank, Working Paper No. 2067.

Maurer, H., Grussenmeyer, P., 2015. Financial assistance measures in the euro area from 2008 to 2013 : Statistical framework and fiscal impact. Statistical Paper No. 7, European Central Bank, Frankfurt upon Main.

Millaruelo, A., del Río, A., 2017. The cost of interventions in the financial sector since 2008 in the EU countries. Banco de España, Analytical Article.

Mody, A., 2009. From Bear Sterns to Anglo Irish: How Eurozone sovereign spreads related to financial sector vulnerability. International Monetary Fund, Washington, D.C., Working paper 9/108.

Schnabel, I., Schüwer, U., 2016. What drives the relationship between bank and sovereign credit risk? German Council of Economic Experts, Working Paper 07/2016.

Sgherri, S., Zoli, E., 2009. Euro area sovereign risk during the crisis. IMF Working Paper 09/222.

Tagkalakis, A., 2012. The effects of financial crisis on fiscal positions. Bank of Greece, Working Paper 145. 


\section{Appendix A. Financial interventions and their classification}

I accordance with the European Commission's Excessive Deficit Procedure guidelines, the various European countries have published data on government interventions carried out by public authorities to support the financial sector. Since 2009 Eurostat has regularly collected and published this data for EU member states. This section discusses the various interventions in detail and analyzes their effect on the government's immediate financing requirement. We classify them into two broad categories: (1) Direct assistance - support measures that increase the government's financing requirement immediately; and (2) Contingent guarantees - support that will increase the financing requirement over time, as and when the loss materializes. ${ }^{15}$

1. Capital injection to support financial institutions: These are capital transfers to cover current or expected losses (or repetitive losses). Usually, they are large, infrequent and something-for-nothing transfers of wealth from governments to a public or private institution. The government receives no income in return for these transactions (i.e. $i_{a, t}=0 \forall t$ ). Thus they increase the sovereign financing need immediately, and we classify them here as direct assistance.

2. ACquisition or PURCHASE of Equities or other DEBT SECURITIES (at or above the market price): These also work as capital transfers; however, in these financial transactions, the government receives a financial asset in return for providing funds. Thus it implies a change in the government's assets as well as a change in liabilities. These assets later become a source of indirect revenue via dividends (for equity) and interest receivable (for loans and other debt securities). The purchase of these financial instruments increases the government's financing requirement immediately (hence, they are classified as direct assistance for our purpose) though a large amount can be recovered by the future sale of these securities. Note that the net cost of these acquisitions is not just the capital transfer resulting from the difference between the market value and the price paid during acquisition. If the government needs to issue new debt to finance these transactions, the government has to pay an interest cost on these borrowings until these assets are sold and loans are repaid.

3. Provision of LOANS: These are direct lending to financial institutions and hence are classified as targeted intervention for our purpose. If there is a written or irrefutable evidence that the loan or a part of it will not be paid, then it is considered as a capital transfer. Any subsequent cancellation or forgiveness of loans are recorded as capital transfer in the subsequent period as and when it happens.

4. Debt Assumption: This is a special form of debt refinancing, involving three parties -

\footnotetext{
${ }^{15} \mathrm{We}$ use the work financing and borrowing in a different context here. If the financing requirement for governments goes up, the government can pay this amount by using different means one of which is by raising money in the capital markets via issuing new debt security. Thus not all financing requirements may result in direct borrowing.
} 
the creditor, the original debtor, and a new debtor, where the new debtor assumes the debt obligation by replacing the old debtor. This involves two simultaneous transactions - the first transaction cancels the original debtor's obligation, and the second transaction creates a new debt contract between the creditor and the new debtor. The first transaction is classified as a capital transfer (as in the case of debt forgiveness), and the second transaction involves the creditor's acquisition of the new debt instrument issued by the assumer. ${ }^{16}$ Thus this also raises immediate financing needs for the governments though the schedule of obligations will be dictated by the original debt contract. ${ }^{17}$

5. Defeasance structures: These are entities incorporated as a special entity by the government to address specific aspects of the turmoil. In general, the entity acquires nonperforming assets from the financial institutions at equal or above the market price (capital transfer) and so raises the need for immediate financing. It usually has no autonomy and its sole purpose is to conduct specific objectives set by the owner. These defeasance bodies can also transfer an additional burden on the sovereign's balance sheet if assets continue to underperform. Since the government will be responsible for all future liabilities, it can create additional financing needs. Assets and liabilities of other entities which are reclassified from the financial sector to the general government do not add to the financing burden immediately, though usually they are created with government support to start with. It should be remembered that in the case of government-owned defeasance bodies, the proceeds from the future sale of assets can offset the fiscal costs related to government interventions.

6. Guarantee on assets or liabilities outside general government: These are guarantees which provide assurances to the creditor that, should a debtor (here the financial institutions) be unable to meet its liability, the guarantor (here the government) will meet it the debtor's behalf. The contract usually specifies the specific conditions that must be fulfilled before the guarantor takes responsibility. Guarantees are granted in relation to deposits or borrowing or might be extended to the value of assets in some circumstances. The guarantees result in no direct cost for the government unless they are called. Here we classify them under contingent guarantee.

7. SeCurities issued Under The Liquidity SCHEME: These are temporary exchanges of financial assets which are carried out by the national central banks to improve the liquidity of financial institutions within the euro area. These are securities lending operations in which governments exchange government securities with private banks based on collateral in the form of discounted asset back securities or covered bonds. The transactions are recorded as back-to-back repurchase agreements rather than as securities lent by the government so that the economic ownership still rests with the government. These are short duration contracts with the risk of loss expected to be very small (Maurer and Grussenmeyer (2015)). As

\footnotetext{
${ }^{16}$ OECD: Glossary of statistical terms

${ }^{17}$ The debt contract can also be modified at the time of transaction based on mutually agreed terms.
} 
the assets are government owned, the ultimate liability lies with the government in case of default. So we classify them as contingent guarantees of the government.

8. Guarantee on Special purpose entities: Any other additional guarantee granted to public or private institutions or special purpose entities not yet covered are classified under this category. We classify them under the contingent guarantee for our current purposes.

\section{Appendix B. Other variables}

\section{Appendix B.1. Country level financial sector characteristic}

The financial sector characteristics data are from banking Structural Financial Indicators (SSIs) which are collected annually by the ECB as part of its supervisory and prudential statistics (Source). Economic dependence on financial institutions is proxied by the total domestic assets of all credit institutions (SizeFI) as a multiple of GDP. To measure asset concentration, we use two different measures:

1. Shares of the 5 largest credit institutions (CIs) in total CI assets (ShareTop5CI)

2. Herfindahl index for credit institutions $(H I)$ is obtained by summing the squares of the market shares of all the credit institutions in the banking sector

$$
H I=\sum_{i=1}^{n}\left(\frac{X_{i}}{X}\right)^{2}
$$

where, $n$ is the total number of CIs in the country, $X_{i}$ is the total assets of CI $i$ and $X=\sum_{i=1}^{n} X_{i}$ is the total assets of all CIs in the country.

Figure B1 plots the average shares of the top 5 largest credit institutions for our sample countries between 2007 and 2016 .

\section{Appendix B.2. Country governance indicators}

Data on a country's perceived government effectiveness are included in the analysis to account for country characteristics that may affect the sovereign's bailout strategy. The data come from the Worldwide Governance Indicators project and are provided by the World Bank. In particular, the indicator for government effectiveness captures "perceptions of the quality of public services, the quality of the civil service and the degree of its independence from political pressures, the quality of policy formulation and implementation, and the credibility of the government's commitment to such policies." The indicator is based on survey responses from enterprise, citizen and expert respondents and is produced by a variety of institutes, international organizations, and private sector firms. ${ }^{18}$

The indicators are available on a yearly basis and generally range from -2.5 (weak governance) to 2.5 (strong governance). For our sample, the government effectiveness ranges from -0.05 (Bulgaria 2008) to 2.35 (Denmark 2007). Figure B2 illustrates the average level of these indices for the individual countries for the period 2007-2016.

\footnotetext{
${ }^{18}$ Source: www.info.worldbank.org/governance/wgi/. See also Kaufmann et al. (2010) for a description of the data.
} 
Figure B1: Average share of the biggest five credit institution (CI) in total CIs assets

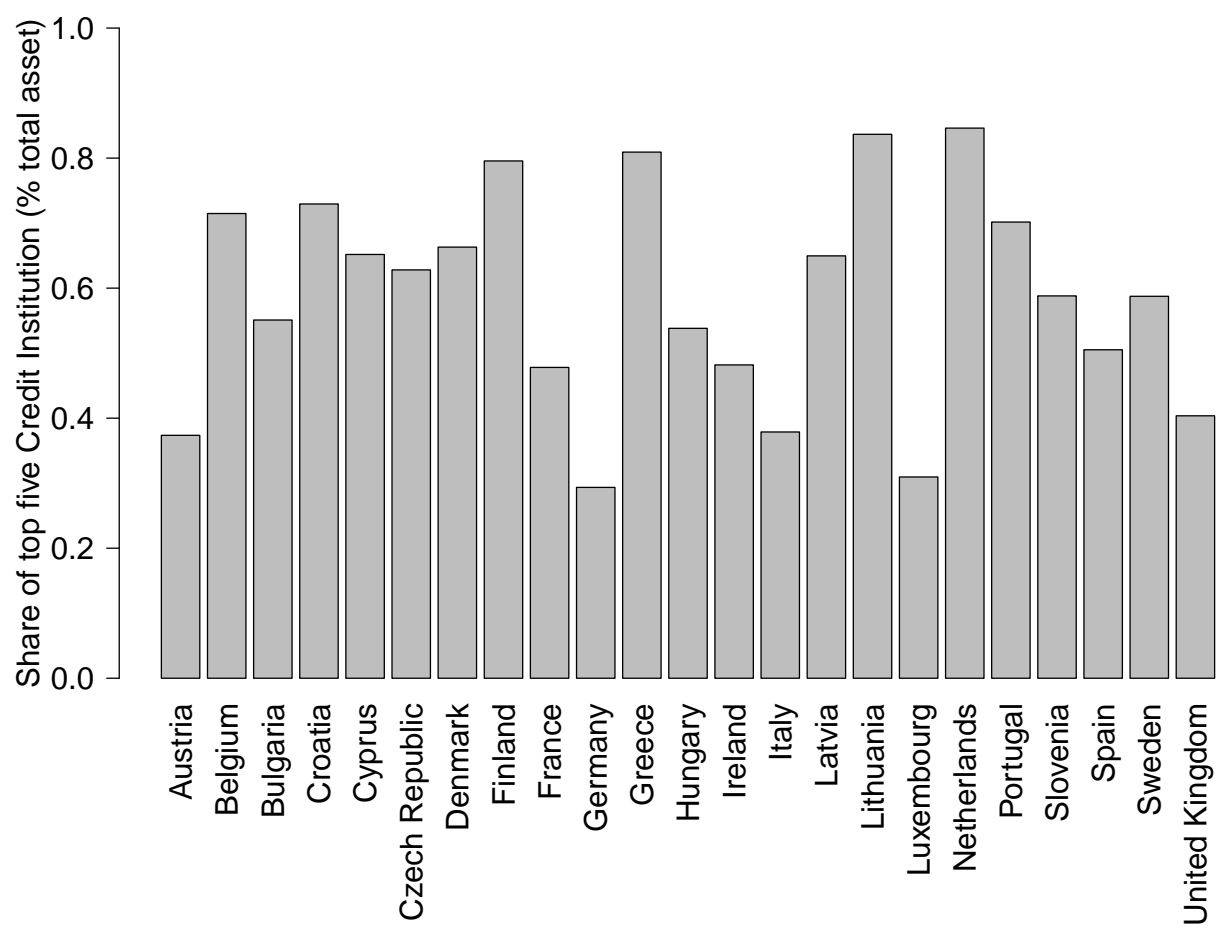

\section{Appendix B.3. Macroeconomic indicators}

We use GDP in nominal terms (in national currency) to study the effect of country size. We use the gross consolidated debt and debt-to-GDP ratio as the current total government liability. The increasing debt level is the direct measure via which government interventions are translated into potential risk for the sovereign ${ }^{19}$ Gross public debt is also the most affected indicator and has been widely cited as the major source of weakness and concern for the sustainability of public finances in the euro area. However, the reality was far more complex: a close look at the government balance sheets suggests that large increases in public debt were accompanied by the acquisition of assets in the financial sector and shifts in their financial portfolio and cash reserve. GDP, Debt-to-GDP ratio and government consolidated gross debt data come from Eurostat. ${ }^{20}$ We also consider inflation and unemployment rate as a proxy for the current macroeconomic condition.

\section{Appendix B.4. Uncertainty and market sentiment indicators}

WUI: The World Uncertainty Index (WUI) is defined using the frequency of the word 'uncertainty' in the quarterly Economist Intelligence Unit country reports. In general, WUI spikes

\footnotetext{
${ }^{19}$ Note that this does not include the contingent liability of the sovereigns.

${ }^{20} \mathrm{http}$ ://ec.europa.eu/eurostat/data/database - Database by themes - Economy and finance - Government statistics (gov) - Government finance statistics (DP and ESA 2010) (gov_gfs10) - Quarterly government finance_statistics (gov_10q) - Quarterly government debt (gov_10q_ggdebt)
} 
Figure B2: Average level of government effectiveness as measured by the World Bank - WGI

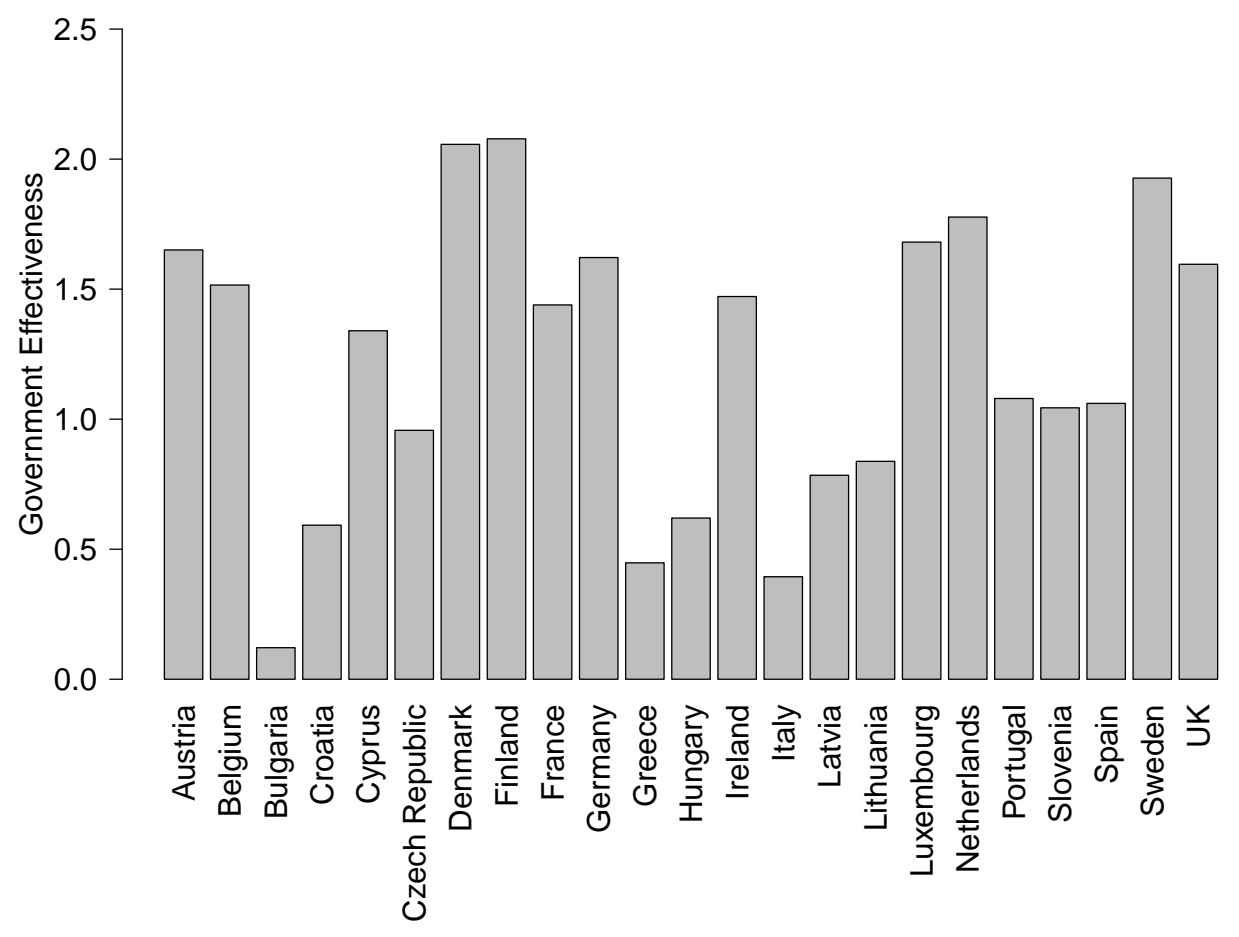

are more synchronized within advanced economies and between economies with tighter trade and financial linkages. Source: www.policyuncertainty.com

ESI: The Economic Sentiment Indicator (ESI) is a composite indicator made up of five sectoral confidence indicators with different weights: Industrial confidence indicator, Services confidence indicator, Consumer confidence indicator, Construction confidence indicator, and Retail trade confidence indicator. Confidence indicators are arithmetic means of seasonally adjusted balances of answers to a selection of questions closely related to the reference variable they are supposed to track (e.g., industrial production for the industrial confidence indicator). Surveys are defined within the Joint Harmonised EU Programme of Business and Consumer Surveys. The economic sentiment indicator (ESI) is calculated as an index with a mean value of 100 and a standard deviation of 10 over a fixed standardized sample period. Data are compiled according to the Statistical classification of economic activities in the European Community. Source: DG ECFIN 
Table B.1: Summary statistics

\begin{tabular}{|c|c|c|c|c|c|c|c|}
\hline Statistic & $\mathrm{N}$ & Mean & St. Dev. & Min & $\operatorname{Pctl}(25)$ & $\operatorname{Pctl}(75)$ & Max \\
\hline SovYield & 230 & 3.95 & 2.73 & 0.09 & 2.05 & 4.77 & 22.50 \\
\hline DirectAssistance (\% of GDP) & 230 & 4.54 & 7.37 & 0.00 & 0.00 & 6.20 & 49.00 \\
\hline ContingentGuarantee (\% of GDP) & 230 & 6.06 & 19.33 & 0.00 & 0.00 & 4.80 & 188 \\
\hline Government liability excluding financial assistance (GovLiabExclFA) & 230 & 63.17 & 33.14 & 7.80 & 38.16 & 81.88 & 169.63 \\
\hline Size of financial sector relative to GDP (SizeFI) & 212 & 1.93 & 1.34 & 0.03 & 0.64 & 3.11 & 5.76 \\
\hline Share of top 5 credit institution (ShareTop5CI) & 219 & 58.26 & 17.01 & 22.00 & 44.46 & 69.47 & 97.28 \\
\hline Herfindal Index (HI) & 224 & 0.10 & 0.07 & 0.02 & 0.06 & 0.12 & 0.37 \\
\hline Gross Domestic Product (in billion euros) & 230 & 561.03 & 783.89 & 17.59 & 44.21 & 628.02 & $3,144.05$ \\
\hline Inflation & 230 & 1.87 & 2.20 & -1.68 & 0.36 & 2.86 & 15.25 \\
\hline Unemployment rate & 230 & 9.60 & 4.92 & 3.46 & 6.20 & 11.48 & 27.48 \\
\hline Governance Effectiveness (GovEff) & 230 & 1.22 & 0.56 & -0.05 & 0.71 & 1.64 & 2.35 \\
\hline World Uncertainty Index (WUI) & 210 & 0.20 & 0.14 & 0.00 & 0.10 & 0.28 & 0.99 \\
\hline Economic Sentiment Indicator (ESI) & 230 & 97.31 & 9.40 & 72.17 & 91.12 & 104.02 & 117.48 \\
\hline
\end{tabular}




\section{UBIREA}

Institut de Recerca en Economia Aplicada Regional i Pública

Research Institute of Applied Economics

\section{Universitat de Barcelona}

Av. Diagonal, $690 \cdot 08034$ Barcelona

WEBSITE: www.ub.edu/irea/ • CONTACT: irea@ub.edu 